\title{
1a-Hydroxyvitamin $D_{3}$ およびその 関連化合物の合成研究
}

一活性型ビタミン $\mathrm{D}_{3}: 1 \alpha, 25-(\mathrm{OH})_{2}-\mathrm{D}_{3}$ の合成アナログを求めて

\section{金子 主 税*}

Synthetic Studies of $1 \alpha$-Hydroxyvitamin $\mathrm{D}_{3}$ and its Related Compounds In Search of New Synthetic Analogues of the Active Metabolite of

Vitamin $\mathrm{D}_{3}: 1 \alpha, 25-(\mathrm{OH})_{2}-\mathrm{D}_{3}$

Chikara KANEKO*

\section{I. はじめに}

最近のビタミンD研究における最も重要な知見は 1967 年から1972年にかけて行なわれたビタミンDの代謝の研
らにいくつかの代謝産物に移行するが，そのうち現在ま でに構造決定されたものは $1,25-(\mathrm{OH})_{2}-\mathrm{D}_{3}{ }^{4 \sim 5)}, 24,25-$ $(\mathrm{OH})_{2}-\mathrm{D}_{3}^{6,7, * 2)}$ および $25,26-(\mathrm{OH})_{2}-\mathrm{D}_{3}$ である9 。

このうち，1,25-(OH) $-\mathrm{D}_{3}$ が現在知られているとこ

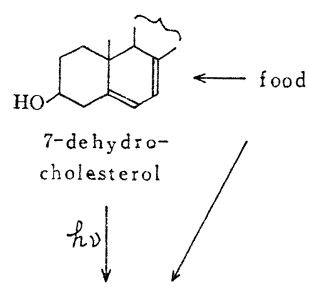<smiles>C=C1CCC(O)CC1=CC=C1CCCC2(C1)C1CCC2C(C)CCCC(C)C1</smiles>

(1936)

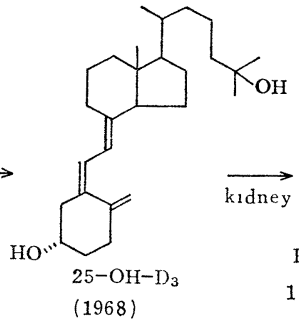

(1968)

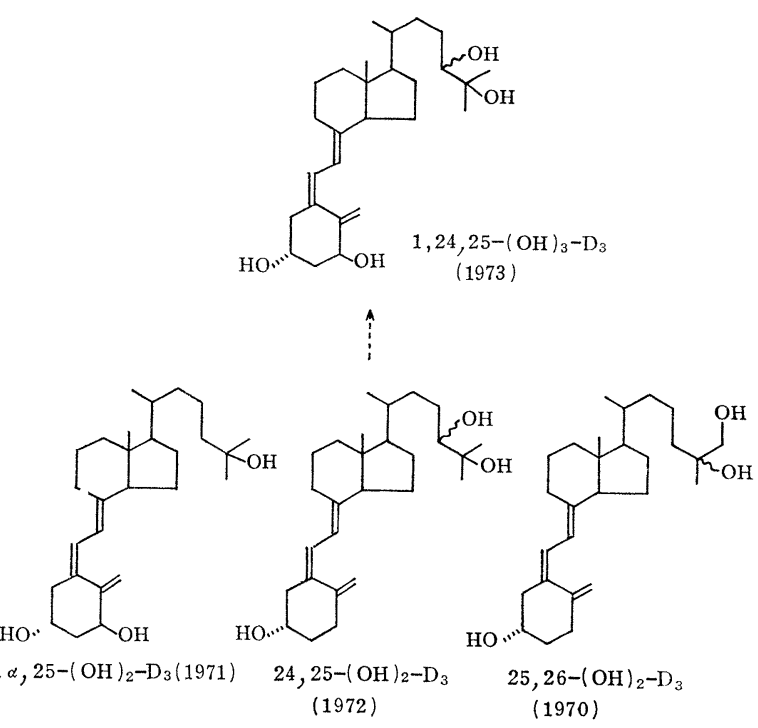

(1970)

図 1 同定された $\mathrm{D}_{3}$ の代謝産物の構造とその代謝経路。（）内はその構造決定がなされた年度

究とその結果として得られた代謝物質の発見である。す なわち,ビタミン $\mathrm{D}_{3}{ }^{* 11}$ はまず肝でその 25 位の炭素が水 酸化され 25- $\mathrm{OH}-\mathrm{D}_{3}$ となる ${ }^{1 \sim 3)}$ 。この $25-\mathrm{OH}-\mathrm{D}_{3}$ はさ

* 東京医科歯科大学医用器材研究所化学部(

* Research Institute for Medical and Dental Engineering, Tokyo Medical and Dental University,
*1) この総説では vitamin $\mathrm{D}_{3}$ (cholecalciferol) を $\mathrm{D}_{\mathbf{8}}$ と略す。同様 に tachysterol $_{3}$ を $T_{3}$ と略す。したがってたとえば $1 \alpha, 25-$ dihydroxycholecalciferol t $1 \alpha, 25-(\mathrm{OH})_{2}-\mathrm{D}_{3}, 25$-hydroxycholecalciferol を $25-\mathrm{OH}-\mathrm{D}_{3}$, dihydrotachysterol ${ }_{3}$ を $\mathrm{DHT}_{\mathrm{s}}$ な どと表示する。

*2） $24,25-(\mathrm{OH})_{2}-\mathrm{D}_{3}$ の生理作用として主に小腸におけるカルンウムの 輸送を促准するが，骨からのカルンウムの溶出に対する作用はほと んどないことが報告されている7。 。た低カルンウム血の動物に $24,25-(\mathrm{OH})_{2}-\mathrm{D}_{3}$ を与えると $1,24,25-(\mathrm{OH})_{3}-\mathrm{D}_{3}$ となるが， しか ᄂ $24,25-(\mathrm{OH})_{2}-\mathrm{D}_{3}$ は低カルンウム血の動物では荚際には作られ ないことから 8 , 1, 24, 25- $(\mathrm{OH})_{8}-\mathrm{D}_{3}$ は現実には存在しえない代謝 産物といえよ 5 。 
ろでは最も生理活性の高い代謝産物であり現時点でビタ ミン $\mathrm{D}_{3}$ の最終活性代謝産物と考えられている。この物 質を生ずる過程つまり $25-\mathrm{OH}-\mathrm{D}_{3}$ の $1 \alpha$ 位の水酸化は 腎で起ることが確められている ${ }^{10,11)}$ 。そして，このもの はさらに腎から標的器官である小腸と骨組織に移行して いわゆるD作用を発現するわけである。

$\mathrm{D}_{3}, 25-\mathrm{OH}-\mathrm{D}_{3}$ はもとより, $24,25-(\mathrm{OH})_{2}-\mathrm{D}_{3}$ と 25 , $26-(\mathrm{OH})_{2}-\mathrm{D}_{3}$ を腎摘動物においてはまったく D 作用を 示さない。したがって $1 \alpha, 25-(\mathrm{OH})_{2}-\mathrm{D}_{3}$ は人工腎臓を 使用する患者に代表される袩不全患者におけるカルシウ ムの代謝異常の改善薬として臨床医学の立場加らも多く の興味と期待を集めている。

この $1 \alpha, 25-(\mathrm{OH})_{2}-\mathrm{D}_{3}$ は発見当初小腸によるカル シウムの輸送を大きく促進する物質として注目された $か^{4}$,5,12 14), その後, 骨のカルシウムの溶出も $25-\mathrm{OH}-$ $\mathrm{D}_{3}$ より急速に 促進すること がわかってきた ${ }^{15)}$ 。らにご く最近このものは静注また は腹腔内注射等の非経口投与 によって長期間与え続けると 持続的に作用を発現するが経 口投与では連日投与すると一 週間で活性を示さなくなるこ とが報告されている*3),16,17)。 生化学者にとって現在, ビ タミンDはビタミンであると 同時にホルモンとしてとらえ られている。ホルモンの定義 は細胞から分泌されてその分 泌が product inhibition に よって制御されていることで ある。したがって活性型ビタ ミンDはホルモンとしてその

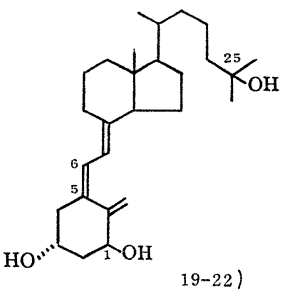
$1 \alpha, 25-(\mathrm{OH})_{2}-\mathrm{D}_{3}$

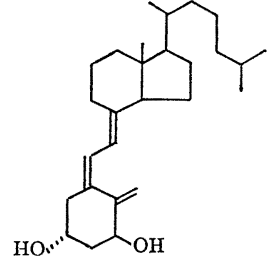

$1 \alpha-\mathrm{OH}-\mathrm{D}_{3}$

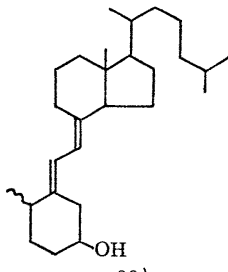

$\mathrm{DHT}_{3}$
貢献したわけで，今後もビタミンD代謝の機構に対する より詳細な研究は慢性腎不全患者, 副甲状線機能低下 症*4)などのビタミンDの代謝系路の障害に起因する骨 の疾患の治療に大きく貢献するであろら。

合成化学者の立場からすれば,すでにいくつかのグル 一プが成功している $1 \alpha, 25-(\mathrm{OH})_{2}-\mathrm{D}_{3}$ の化学合成 ${ }^{19222}$ をさらに容易にするか，または生化学者との緊密な協力 のもとに毒性が少なくかつ選択的に働く会 $10,25-(\mathrm{OH})_{2}$ $\mathrm{D}_{3}$ のアナログをより安価にできる合成法で作りうるな らば腎不全患者などへの応用をさらに効果的にすること ができるわけである。

現在この種のアナログとして 図 2 に示す化合物が開 発されている*5)。

これらのアナログは腎摘動物では $\mathrm{D}_{3}$ 自身や $25-\mathrm{OH}-$ $\mathrm{D}_{3}$ がまったく作用を発現しないのに対し，程度の差は

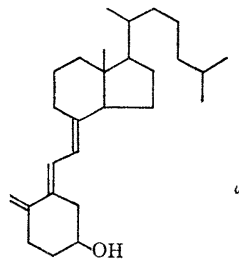

25)

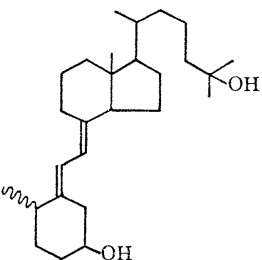

24) 25-OH-DHT 3

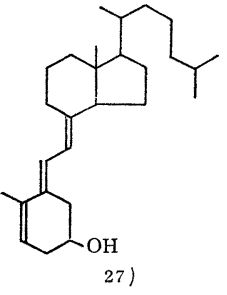

$\mathrm{CSOT}_{3}$

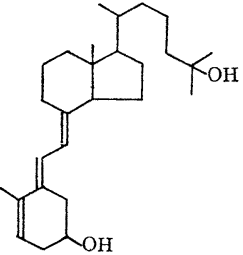

27)

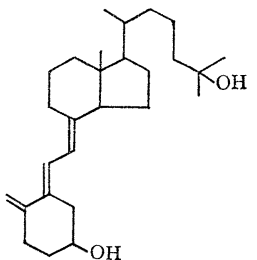

26)
図 2 腎摘動物でD作用を発現できる $1 \alpha, 25-(\mathrm{OH})_{2}-\mathrm{D}_{3}$ とそのアナログ
分泌 (生成) がどのように制御されているかを知ること が現在のもっとも重要な課題の一つとなっている。また これらの $\mathrm{D}_{3}$ がカルシウムイオンの吸収ばかりか，リン 酸の輸送にも密接にかかわっていることも明らかとなっ ており り ${ }^{18)}$ れらの機構も活発な研究の対象となってい る。

ビタミンDの研究の究極の目的はもちろん臨床医学に 役立つことである。そしてまず活性型ビタミン $\mathrm{D}_{3}$ つま り $1 \alpha, 25-(\mathrm{OH})_{2}-\mathrm{D}_{3}$ の発見はこの目的の達成に大きく

*3）このことは, $1 \alpha, 25-(\mathrm{OH})_{2}-\mathrm{D}_{3}$ を連続経口投与するとその吸収部位 (小腸) において $1 \alpha, 25-(\mathrm{OH})_{2}-\mathrm{D}_{3}$ を分解する酸素の活性が高ま り分解されてしま5ためその活性が発現されなくなるのかもしれな い。1 回の投与では静注と同様の活性を発現することは, 少なくと もこのものが小腸から吸収されることを示している。
あるもののいずれも $1 \alpha, 25-(\mathrm{OH})_{2}-\mathrm{D}_{3}$ と同椂の活性を 示す。

図 2 に示された構造を比較してわかるように，これ らの活性アナログに共通した特徴はいゔれも $10,25-$ $(\mathrm{OH})_{2}-\mathrm{D}_{3}$ の 1 位の炭素に相当する場所に水酸基をも。 ていることである。

これらの活性 $\mathrm{D}_{3}$ 類の臨床への応用はまだ始まったば かりであるが，多くの症例では大きな効果をあげてい

*4）生体内てのカルンウムイオンの濃度は，ビタミンD，副甲状線ホル モン (PTH) およびカルントニンなとにより制御されている。

*5）一般に 5,6-cis 類 $\left(1 \alpha, 25-(\mathrm{OH})_{2}-\mathrm{D}_{3}\right.$ そ $\left.1 \alpha-\mathrm{OH}-\mathrm{D}_{3}\right)$ にくらへ 5,6-trans 類 $\left(\mathrm{DHT}_{3}\right.$ やtrans $\left.-\mathrm{D}_{3}\right)$ は作用加はるかに弱い。また 一般的に比較すると前者は骨程動員作用より小腸からの Ca の吸収 作用の方が強いが，後者では逆に骨程動員作用の方か強いことか知 られている。 
る*6)。

われわれ（東京医科歯科大学医材研・化学部） む1971 年まで DeLuca 教授のもとで活性型ビタミンDの研究 を行なっていた本学齒学部の須田助教授が帰国されたの を機として石川教授の全面的協力のもとに須田博士の属 する佐々木教授をはじめとする生化学教室の人々と密接 な協同研究を開始し, 主に $1 \alpha-\mathrm{OH}-\mathrm{D}_{3}$ ならびに $\mathrm{A}$ 環の 水酸化された $\mathrm{D}$ 類の合成とその生理作用の検討を行ない つつ現在に至っている。

すでに活性型ビタミン D 類合成 ${ }^{29 \sim 31)}$ や代謝 ${ }^{17,27,32 \sim 38)}$ についてはいくつかの新しいすぐれた総説があるのでこ こではこの総説に独自性をもたせるためこの協同研究の 推移 (端緒, 発展および現状) を合成面に重点をおいて 述べ，あわせて主に1972年以後の他のグループの合成研 究も紹介したい。

われわれの研究は始めから活性代謝産物の本体である $1 \alpha ， 25-(\mathrm{OH})_{2}-\mathrm{D}_{3}$ を目標とせずそのアナログであり当 時末知物質であった $1 \alpha-\mathrm{OH}-\mathrm{D}_{3}$ をめざしてはじめられ た。したがって以下まず $1 \alpha-\mathrm{OH}-\mathrm{D}_{3}$ の合成について述 べ順次 $1 \alpha, 25-(\mathrm{OH})_{2}-\mathrm{D}_{3}$, 側鎖の水酸化された $\mathrm{D}_{3}$ 類, $\mathrm{A}$ 環の水酸化された $\mathrm{D}_{3}$ 類の合成についてのべることに する。

\section{II. $1 a-O H-D_{3}$ の合成}

\section{1a-OH-Cholesterol を中間体亡する Choleste-}

はじめ, 褐藻類から大量に得られる fucosterol を原料 とし desmosterol を経てコレステロール側鎖に水酸基を 導入する方法を開発しつつあった東工大の池川, 森崎の グループが $1 \alpha, 25-(\mathrm{OH})_{2}-\mathrm{D}_{3}$ の合成を行ないつつある ことが判明していたので，われわれは直接この物質の合 成を行ならことをやめ，生化グループと種々討論のすえ 当時未知物質であった $1 \alpha-\mathrm{OH}-\mathrm{D}_{3}{ }^{* 7)}$ の合成を次の五点 に要約される理由にもとずいて企画した：

i）当時, $1 \alpha, 25-(\mathrm{OH})_{2}-\mathrm{D}_{3}$ のほか，5,6-trans- $\mathrm{D}_{3}$ や $\mathrm{DHT}_{3}$ が腎摘動物においてビタミンD作用を発現で きることが判明していた。図2からもわかるように これら 5,6-trans 型の二つのアナログの $\mathrm{A}$ 噮 部は $\mathrm{D}_{3}$ と比較した場合 5,6-位の二重結合に対し $180^{\circ}$ 回 転しておりその $3 \beta$ 位の水酸基が $\mathrm{D}_{3}(5,6-c i s$ 型) における $1 \propto$ 位をしめることになる。このことから $1 \alpha$-水酸基を作用発現の essential function と仮定 した*8)。

i1） $1 \alpha-\mathrm{OH}-\mathrm{D}_{3}$ を合成しその生理作用から i) の仮説 を支持するデータを得ることは生化学的見地から重 要な知見であると考えた。

iii）合成的見地から $1 \alpha-\mathrm{OH}-\mathrm{D}_{3}$ が腎摘動物にDとし ての生理作用を示した場合安価な cholesterol を原 料とし得るので工業的に有利と考えた。

iv) 肝が正常な動物であれば生体(腎摘動物を含め) 内で $1 \propto, 25-(\mathrm{OH})_{2}-\mathrm{D}_{3}$ に代謝される可能性が考え

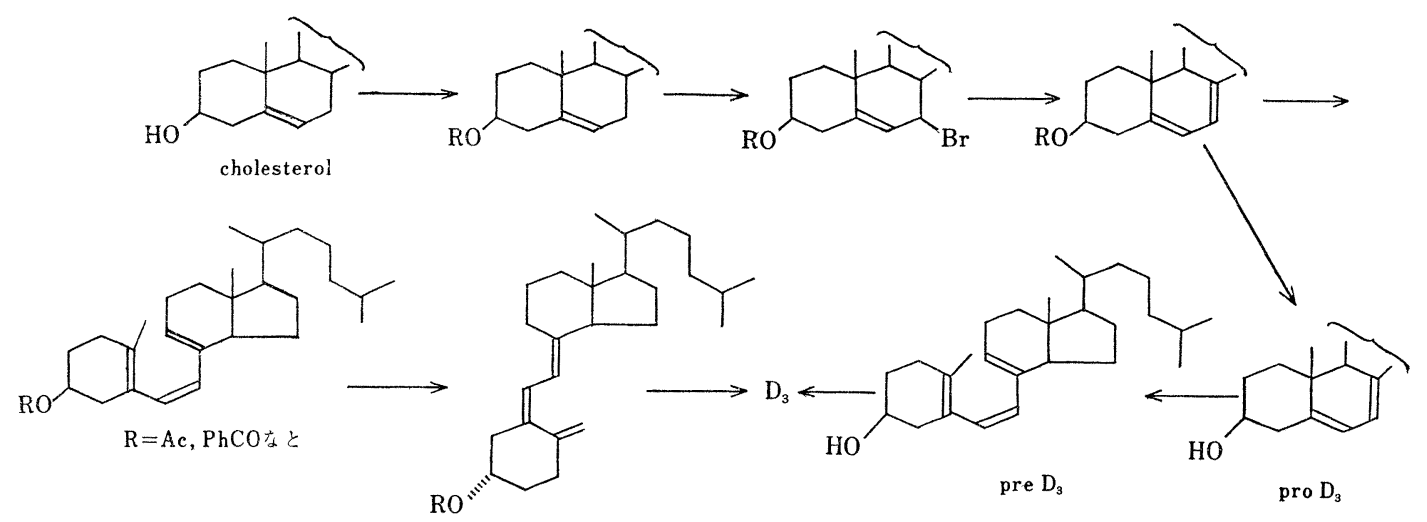

图 3 Windaus 法 (1935 )

rol からの部分合成 1972年われわれが実際に本研究 に着手した当時 $1 \alpha, 25-(\mathrm{OH})_{2}-\mathrm{D}_{3}$ の発見者であるアメ リカの DeLuca と英国の Kodicek の二つのグループを

*6） 1, 25- $(\mathrm{OH})_{2}-\mathrm{D}_{3}$ の最初の臨床例は1972年 Norman らにより報告 されだ8)。彼らはビタミン $\mathrm{D}_{3}$ の長期投与によってもまったく反応 を示さなかった腎不全患者にニワトリの腎（in vivo）て作った本 品を与えて $\mathrm{Ca}$ 代䂗異常の著しい改善效果をたしかめた。
*7） D類における水酸基の配位は効応する pro-Dに対してなされる(困 3 参照)。

*8）代䂗研究の初期（1967 1969年）にはます $25-\mathrm{OH}-\mathrm{D}_{3}$ 加発見され それか、 $\mathrm{D}_{3}$ 上りも強くからょり速く効果を現わすことか示されした がってこのものか活性 $\mathrm{D}_{3}$ ではないかと考えられた ${ }^{1,39 \sim 41)}$ 。そして

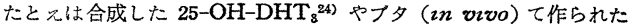

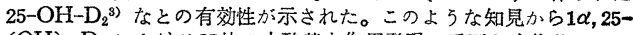
$(\mathrm{OH})_{2}-\mathrm{D}_{3}$ における25位の水酸基も作用発現に重要な官能基である といら考えが本研究開始当時（1972 年初め）から多くの研究者の間 て非常につよかった。 


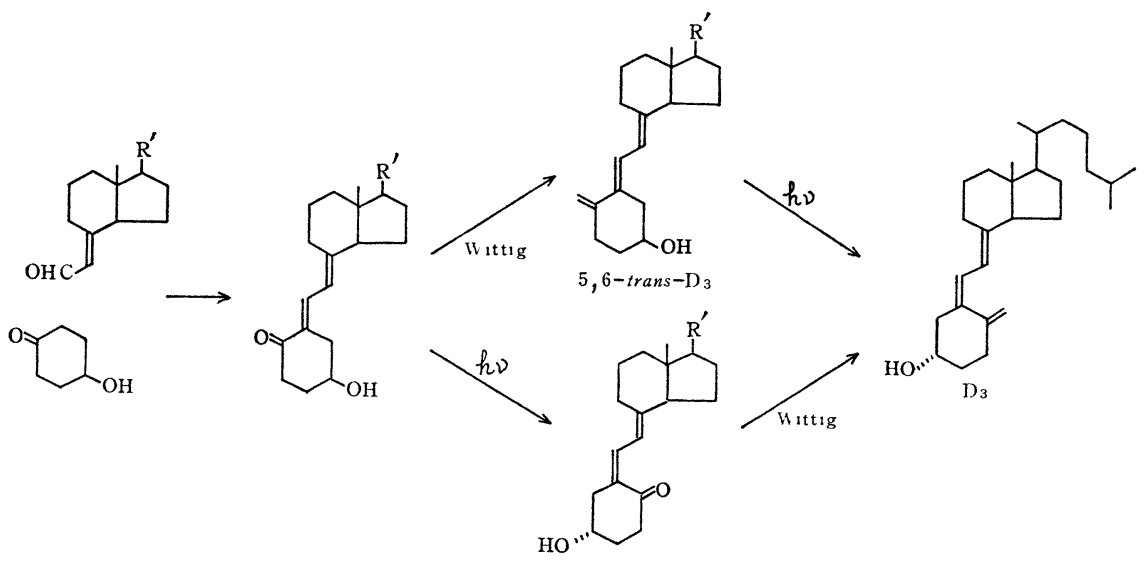

図 4 Inhoffen 法 (1958)<smiles>[R2]O[C@H]1CCC(C)=C(C=[C])C1</smiles>

OR

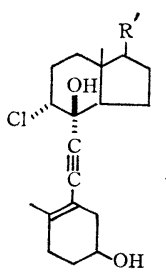<smiles>[R]C1CCC2C(C=CC3=C(C)CCC(O)C3)=CCCC12</smiles>

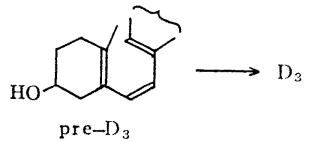

図 5 Lythgoe 法 (1970)

\section{られた*99。}

v） $1 \alpha-\mathrm{OH}-\mathrm{D}_{3}$ にもちいた合成法を $1 \alpha, 25-(\mathrm{OH})_{2}-$

$\mathrm{D}_{3}$ およびその他のアナログの合成に利用できる。

$\mathrm{D}_{3}$ 自身の合成にはすでに 1960 年以前に一般に Win. daus 法および Inhoffen 法と呼ばれる二つの基本的合成 ルートが確立されており, さらに1970年には Lythgoe法 とよばれる第三の合成ルートが開発されていた。これら 三つの方法を図 3〜5 に示す。

図 3 の方法は古く1930年代に Windaus らにより確立 された方法 ${ }^{42)}$ で ergosterol や 7-dehydrocholesterol の UV 照射によるB環の光開裂を含む方法であり，現在も D類の工業的製造法に用いられている。図 4のコース の方法は1958年 Inhoffen ら ${ }^{43}$ によって報告され，ほぼ 同時に Harrison と Lythgoe がコースbに示すように trans-cis isomerization ののちに末端メチレン基を導入 する方法を発表した ${ }^{44)}$ 。れら二つの方法はいずれもま ず 5,6-trans- $\mathrm{D}_{3}$ またはそのアナログを合成しつぎにそ の 5,6-trans 配位の二重結合を UV 照射により天然の Dのもつ 5,6-cis 配位へ異性化させることを特徴として いる。Inhoffen らは当初その fragment を $\mathrm{D}_{3}$ の分解

L*9）この立場はたとえば $\mathrm{D}_{3}$ から $1 \alpha, 25-(\mathrm{OH})_{2}-\mathrm{D}_{3}$ にいたる代謝中間 体である 25-OH- $\mathrm{D}_{3}$ における 25- $\mathrm{OH}$ 基の譏能をDの肝から腎へ の輸送 function と考えることに相当する。
によって得ていたが，後にその全合成にも成功した ${ }^{45)}$ 。 いずれにせよこれらの方法は Windaus の門下から輩出 した Schenck や Havinga らの有機光化学者のD関連化 合物に対する詳細な光化学反応の結果と当時開発された Wittig 反応の応用のうえに完成されたものといえよう。 図 3 や図 4 の方法とは異なり光化学反応をまったく利用 しない全合成ルートが 1970年 Lythgoe らによって完成 された ${ }^{4,47)}$ 。このルートの特徴は直接 $\mathrm{D}_{3}$ をめざさずそ の前駆物質である pre- $\mathrm{D}_{3}$ の合成を目ざした点である (pre- $\mathrm{D}_{3}$ から $\mathrm{D}_{3}$ への変換は熱的な反応である)。また pre- $\mathrm{D}_{3}$ は exocyclic methylene 基をむたないからWittig 反応を使用する必要もないわけである。

以上三つのルートはいずれもそれぞれ合成法として見 た場合偉大なものであるがわれわれの当初の目的の一つ である大量安価な合成を目ざす場合にはやはり cholesterol $\rightarrow$ 7-dehydrocholesterol $\rightarrow \mathrm{D}_{3} \quad$ のコースを踏襲する のが最適であると考えた。したがって $1 \alpha-\mathrm{OH}-\mathrm{D}_{3}$ を目 ざす場合にはまず cholesterol の 10 位への水酸基導入 の方法が問題となった。

文献を調べると 1972 年当時, cholesterol からの $1 \alpha-$ hydroxycholesterol への変換が二つのグループによって 報告されていることがわかった。これら二つの方法の概 


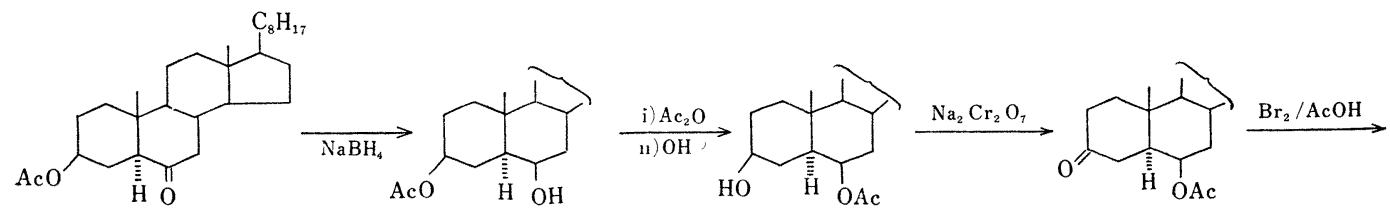

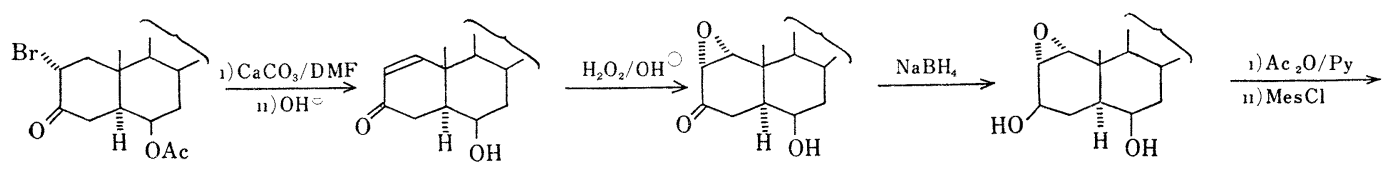

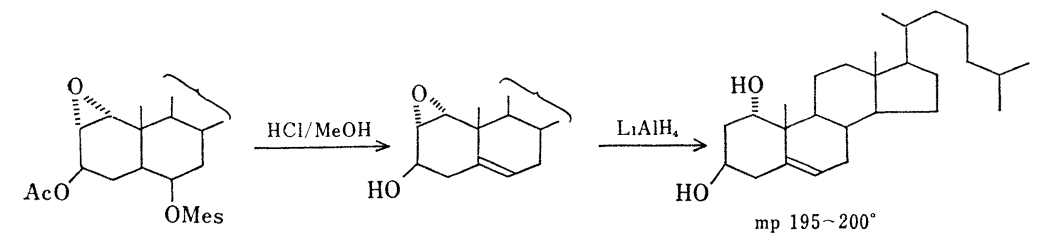

图 6 Pelc, Kodicek の方法 (1970)

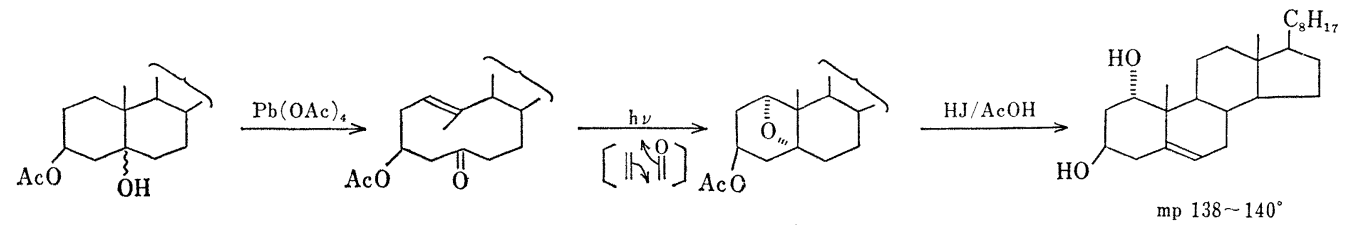

図 7 CIBA-GEIGY 社の方法 (1971)

略を図 6 と 7 に示す。

図6の方法は Pelc と Kodicek によって1970年 に開発されたものであるが行程数が多い点, および その報文の実験の部に 1C-hydoxycholesterol が約 $1 \mathrm{~g}$ 得られたと記載されてあったにもかかわらず， その後このグループが $1 \alpha-\mathrm{OH}-\mathrm{D}_{3}$ の合成を報告し ていなかったなどの点からわれわれはこの方法をも ちいなかっだ(10),48)。これに対し図7に示す Kolvoda

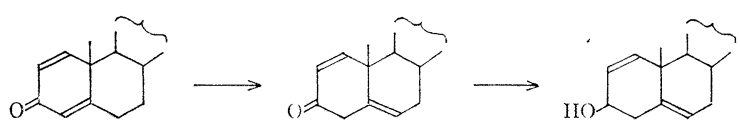
(a) らの CIBA-GEIGY 社の方法は 5-hydroxycholestanol を原料として表示のようにきわめてユニークなものであ り学問的立場から追試再検討するに值する興味あるルー トではあったが，各行程の収率がきわめて悪くやはり合 成法としては満足すべきものとは考えられなかった ${ }^{49)} 。$ そこでわれわれは簡単かつ大量合成にたえる $1 \alpha$-hydroxycholesterol の合成法の確立を目ざして 1972 年 6 月実 際の研究に着手した。そのルートは 図 8 亿示すよらに cholesterol 加ら容易に得られる cholesta-1, 4-dien-3one 出発原料とし $\mathrm{a}, \mathrm{b}$ 二つの step からなっていた。

まず step a は cholesta-1, 4-dien-3-one を deconju-

*10） $1 \alpha, 25-(\mathrm{OH})_{2}-\mathrm{D}_{3}$ は前述したよ $5 に$ Kodicek らと DeLuca らの グループによりほほ同時に生体より発見された。したかってこのグ ループは当然 $1 \alpha, 25-(\mathrm{OH})_{2}-\mathrm{D}_{3}$ の合成とともに $1 \alpha-\mathrm{OH}-\mathrm{D}_{3}$ の合 成にも大きな興味をもっている可能性か強かった。

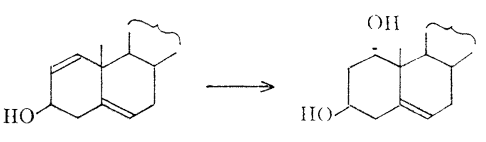

図 8 東医歯大グループの予定スキーム

gation により cholesta-1, 5-dien-3-one となし, ついで そのケトン基を還元して cholesta-1,5-dien-3 $\beta$-ol を得 るものであり, step b はこの 1,5-dienol の一位の二重 結合に選択的に水和反応を行なうというものであった。 step a に示した deconjugation 反応は Ringold ${ }^{50)}$, Shapiro $^{51)}$ および Kruger ${ }^{52)}$ により 図 9 に示すように 各種のステロイド系エノン拈よびジェノン類についてそ の成功例が報告されていた*11)。またこれらの deconjugationされたエノン類が二重結合の移動なしに還元され

\footnotetext{
*11）これらの反応はいすれも強塩基条件下てエノン類をエノール化し， 生したエノレートを kinetic control の条件下て中和することを 骨子としている。これに対しエノールアセテートを経て還元すると いう方法も当時やはり報告されていたか酸性条件の使用は応用範团 の点て難点かあり（たとえは図 9 中の cross conjugated dienone はエノールアセテート形成段階て dienone-phenol 転位に上 りA環の芳香化を起すてあるうことなと)採用しなかった。
} 
<smiles></smiles>

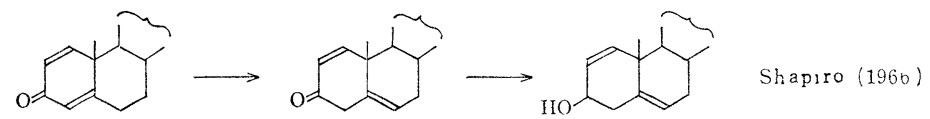

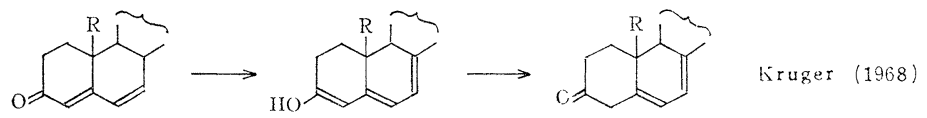
$\mathrm{R}=\mathrm{H}, \mathrm{CH}_{2} \mathrm{OH}, \mathrm{CH}_{2} \mathrm{OAc}$ 坛

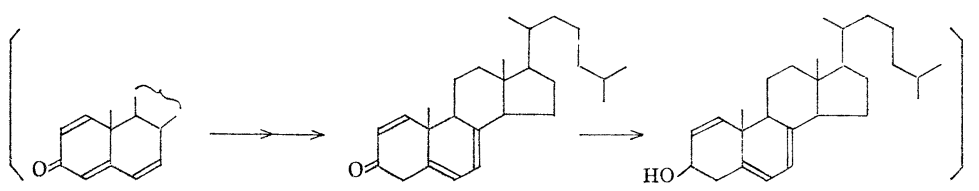

図9各種ステロイドェノン類のデコンジュゲーション反応 $\mathrm{R}=\mathrm{RCO}, \mathrm{Alkyl}$ など

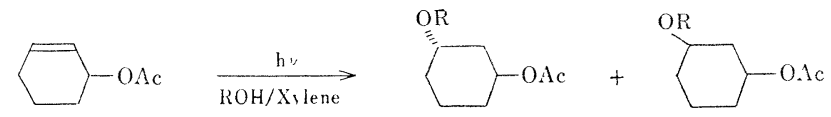

図 10 Cyclic allylalcohol に対方る光極性付加反応の一例
は行なわれておらず図 8-a に示し た二つの化合物の合成例の報告はな かった。また Kruger ${ }^{52)}$ による同条 件下の 4,6-dien-3-one の 5,7-dien -3-one への変換はこの種の反応が 広い応用性をもつことを示唆するば かりでなく将来〔つ内に示したよ うな中間体を経る $1 \propto-\mathrm{OH}-\mathrm{D}_{3}$ のよ り直接的な合成法にも応用しらる可 能性を示しているよらに見えた。

step b に対しては当時 Marshall, Kropp および野崎らによって多く の成功例が報告されていた図 10 に 示すような cyclic allylic alcohol系 八の光化学的水化反応 ${ }^{54)}$ 筑一に検 討することを予定していた。なぜな らこの種の反応を複雑な天然物分子 に店用した例は当時皆無であったか らである。

以上の上うにこのスキーム(図8) は単に $1 \alpha-\mathrm{OH}-\mathrm{D}_{3}$ を作りうるとい る反応もいくつか報告されていた ${ }^{51,53) 。 ~}$

特に Shapiro ら ${ }^{51)} 1966$ 年に17位に水酸基をもつア ンドロスタン系の 1, 4-dien-3-one が高收率で1,5-dien -3-one となることを報告していたがわれわれが知るか ぎりではその後対応する cholesterol系ではこの種の反応

ら点ばかりでなく合成化学の見地からも十分満足できる 内容をもっていると考えた。

実際に step a の反応は deconjugation および還元と 8 Shapiro らの反応条件とほぼ同様の条件下に進行し cholesta-1, 4-dien-3-one 加ら通算して 65〜 75\%の収率

$$
\left.\begin{array}{l}
\mathrm{R}=\mathrm{C}_{8} \mathrm{H}_{17} \\
=\left(<_{0}^{0}\right. \\
=K_{0}^{0}
\end{array}\right]
$$<smiles>[R]C1CCC2C3CCC4=CC(=O)C=CC4(C)C3CCC12C</smiles>

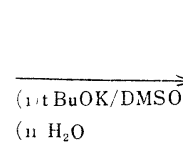

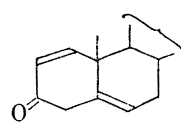

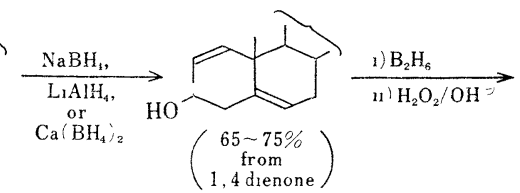<smiles>CC12CCCC(CC(O)[C@H]1O)CC2O</smiles>
$(20 \sim 25 \%)$<smiles>CC[C@@H](O)C12CC(O)CC1=CCC1CCC2CC1</smiles><smiles>[131In]</smiles>
AcO<smiles>[R]C1CCC2C1CCC1C2CC=C2CC(O)C[C@H](O)C21C</smiles>

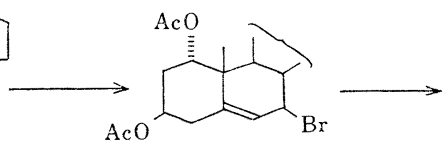
mp $15 \frac{1}{2} \sim 156^{\circ}$<smiles>[R]C1CCC2c3ccc4c(c3CCC12C)C1CCC(C)C1(C)CC[C@H](O)C[C@H]4O</smiles>

図 11 東医蒾大グループの $1 \alpha-\mathrm{OH}$-cholesterol の合成法 (旧法) とその $1 \alpha-\mathrm{OH}_{-} \mathrm{D}_{3}$ への変換ルート (1973) 
で cholesta-1,5-dien-3 $\beta$-ol を合成することができた。

また，同時に中間体である cholesta-1,5-dien-3-one が長期保存にたえる安定な物質であることも判明した。 本品の還元は $0^{\circ} \mathrm{C}$ で $\mathrm{MeOH}$ 中 $\mathrm{NaBH}_{4}$ で容易に進行 しほぼ選択的に $3 \beta$-ol をあたえる。この還元はエーテ ル中 $\mathrm{LiAlH}_{4}$ で行なうこともできるが, $\mathrm{EtOH}$ 中ー $10^{\circ} \mathrm{C}$ で $\mathrm{Ca}\left(\mathrm{BH}_{4}\right)_{2}{ }^{55)}$ をもちいて行ならともっともよい結果 が得られることが判明した。

次に step b にそう 1,2-二重結合一の光水和反応を 種々の条件下で行なったが, 種々の生成物を生じ目的物 の収率を $5 \%$ 以上にあげることができなかった。そこで ただちに hydroboration およびそれに次ぐ酸化反応を 行ならことにした。これは本反応に関する次の二つの知 見に基らくものであった：

(i) diborane の C-C 二重結合への付加反応の速度 は一般にその二重結合への alkyl 置換基の数の増大 につれて減少する。また, この結果得られる alkylborane はアルカリ条件下 $\mathrm{H}_{2} \mathrm{O}_{2}$ により酸化され対 応するアルコールとなるが，その際その部位の配位 は保持される ${ }^{56)}$ 。

(ii) $\mathrm{A}$ およびB 澴不飽和 cholestene $\left(\Delta^{1,2}, \Delta^{2,3}, \Delta^{3,4}\right.$, $\Delta^{4,5}$ および $\left.\Delta^{5,6}\right)$ に扔いて，この方法による水和反 応は常に立体障害の少ない方, つまり C-19 $\mathrm{CH}_{3}$ 基 の反刘側 ( $\alpha$-side) から起ることが Sondheimer ら によって確められていた。たとえば cholest-1-ene はほぼ等量の $1 \alpha$-および $2 \alpha$-hydroxycholestane を 与える ${ }^{57,58)}$ 。
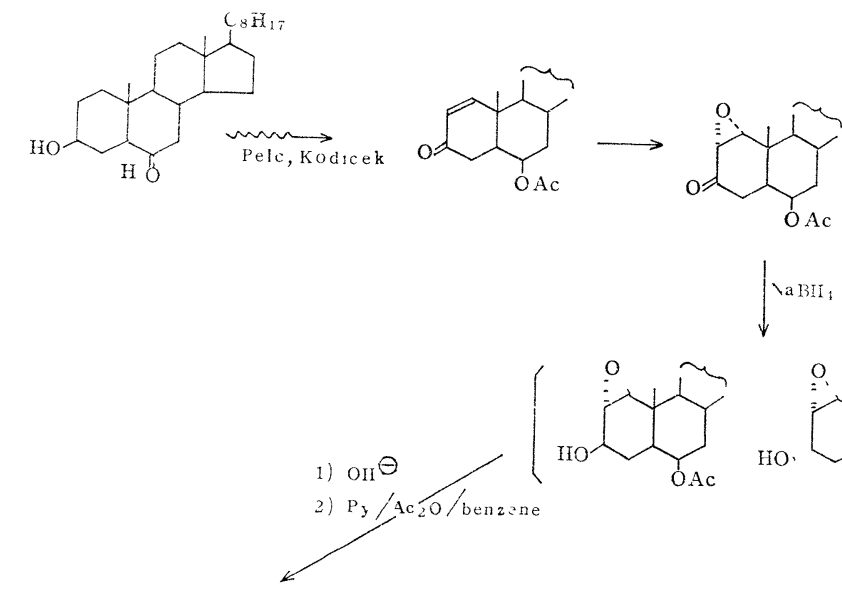
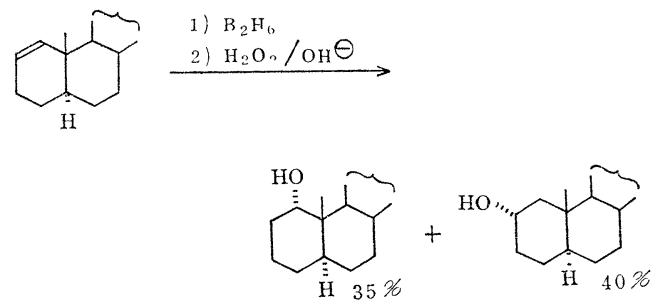

この方法を実際に cholesta-1,5-dien-3 $\beta$-ol に行なっ たところ, 予期したように $1 \alpha-\mathrm{OH}$ 体と $2 \alpha-\mathrm{OH}$ 体を得 ることができた。收率は後者の方がやや高かった。この ようにしてわれわれは 1 $1 \alpha$-hydroxycholesterol の合成 を1972年末に完成することができた。われわれは同時に この反応を androsterone 系括よび pregnenolone 系に も応用しやはり効応する $1 \alpha$-および $2 \alpha$-hydroxy 体を合 成し，この方法が広い応用範囲をもつことを実証*122し た。図 11 にこの方法の概要を示す。

この時点で活性代謝産物の本体である $1 \alpha, 25-(\mathrm{OH})_{2}$ $\mathrm{D}_{3}$ の最初の合成例が Tetrahedron Lett. 紙上にその発 見者の一人である DeLuca ら Wisconsin 大のグルー プにより発表された ${ }^{199}$ 。

その報告における $10-\mathrm{OH}$ 基の導入法は後述するよう に本質的には図 6 に示した Pelc, Kodicek の方法 ${ }^{48)}$ の追 試ということができ，われわれの方法とは明らかに異 なっていた。われわれの合成法については翌年(1973年) の薬学会で報告したが ${ }^{59)}$, この時ほぼ同時に東工大グル ープもアメリカ化学会に抒いてPelc と Kodicek の方法 で合成した $6 \beta$-acetoxy-5 $\alpha$-cholest-1-ene-3-one を原料 とする $1 \alpha$-hydroxycholesterol の合成を発表した ${ }^{60)}$ 。彼らの方 法を図 12 亿示す。

森崎博士の好意により両者の サンプルを直接混融することに より同定し, 両者協議の上, そ れぞれの㘧告を同時に投稿し $た^{61,63)}$ 。この結果, Pelc と Kodicek が合成したと報告した 1 $\alpha$-hydroxycholesterol の融点 はわれわれのものと大きく異な ることがわかり，したがってそ の構造には大きな疑問が持たれ るに到った。このようにして得

*12）この場合 deconjugation stepにお ける分子間縮合を防ぐために，17お よひ20位のケトン基をエチレンケ夕 一ル基として保護しておくことが望 ましい59,61,62)。 


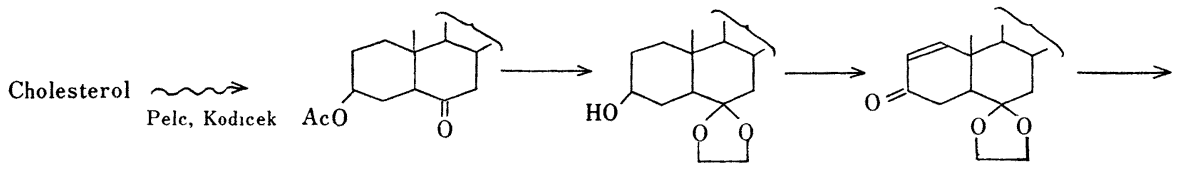

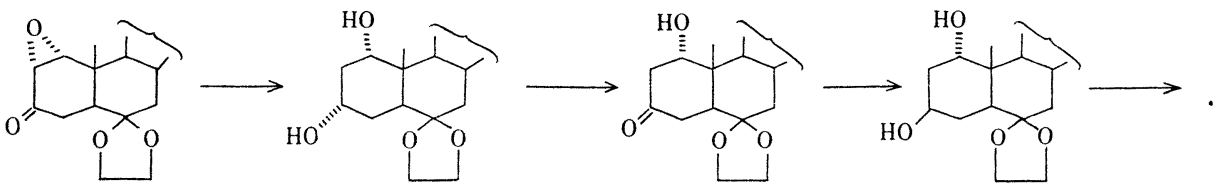

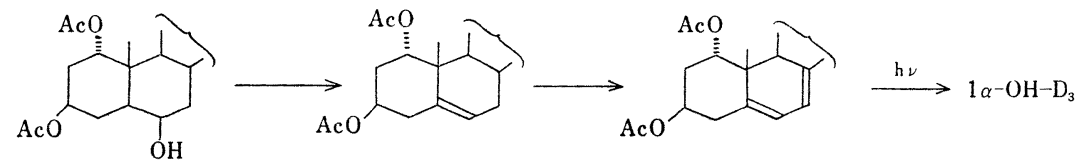

図 13 Wisconsin 大グループの $1 \alpha-\mathrm{OH}-\mathrm{D}_{3}$ の合成ルート (1973)

た 1 $\alpha$-hydroxycholesterol の対応 $\mathrm{D}_{3}$ への変換は図11に 示したように 7-dehydrocholesterol の $\mathrm{D}_{3}$ への変換(図 3 および11参照）と同様に行なった。当初，このスキー ムで 5,7-diene の光開裂が比較的低収率 (1 $1 \alpha$-hydroxy7-dehydrocholesterol $\rightarrow$ pre $-\mathrm{D}_{3} \rightarrow 1 \alpha-\mathrm{OH}-\mathrm{D}_{3}$ の通常は １5\%）であったが，現在ではこの過程は 30〜35\% で 進行するようになっている*13)。この光反応の条件を吟 味中に Wisconsin 大のグループは $1 \alpha, 25-(\mathrm{OH})_{2}-\mathrm{D}_{3}$ の 合成之同じ方法（図13）で $1 \alpha$-水酸基を cholesterol に 導入することに成功し，これを $1 \alpha-\mathrm{OH}-\mathrm{D}_{3}$ となし，正 常および腎摘ラ，トに対するその生理作用とともに報告 した

彼らの報告は $1 \alpha-\mathrm{OH}-\mathrm{D}_{3}$ が腎摘ラットに対し $1 \alpha, 25-$
$(\mathrm{OH})_{2}-\mathrm{D}_{3}$ と同様の活性を示すことを述べており，この 点でわれわれの協同研究の最初の着眼の正しさを実証す るものではあったが，しかしわれわれはその合成はもと よりその生理作用のチェックにおいても遅れをとったこ ととなり，少なからぬ shock を受けた。おれわれは独 自の合成法と副甲状線摘出ラットに対する $1 \alpha-\mathrm{OH}-\mathrm{D}_{3}$ の効果*14)という二つの新規性に重点を置き, その結果 を1973年秋の天然物討論会に金子らが主に合成を ${ }^{65)}$ ，内 分泌学会東部々会に須田らがその生理作用 ${ }^{66}$ について発 表し，同時に Steroidsに原報として投稿した ${ }^{67) 。 ~}$

この間にも $1 \alpha-\mathrm{OH}-\mathrm{D}_{3}$ の合成は Barton ${ }^{68)}$, Furrst ${ }^{69)}$ および Lythgol ${ }^{70)}$ らのグループによりつぎつぎと発表 された。

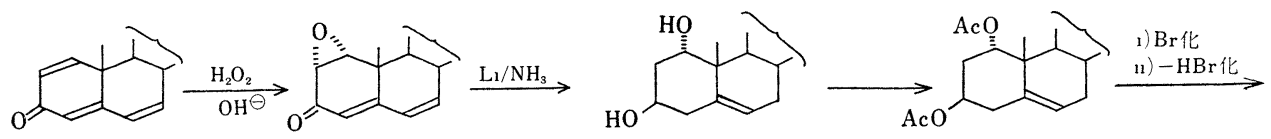
$\mathrm{NH}_{4} \mathrm{Cl}$<smiles>C=C1/C(=C/C=C2\CCCC3(C)C(CCC(C)C)CCC23)C[C@@H](OC(C)=O)C[C@@H]1OC(C)=O</smiles>

図 14 Barton らの方法 (1973)

*13）これらの收率はいすれも消費された原料に対するものてある。

*14） 1,25- $(\mathrm{OH})_{2}-\mathrm{D}_{3}$ を副甲状腺機能低下症の佁療に適用した報告は未だない。しかし，腎の $1 \alpha$-水酸化㗼素を活性化するのは副甲状腺ホルモンであ ることか判明しており 71)，乙たかって須田らの得た10単位の $1 \alpha-\mathrm{OH}-\mathrm{D}_{3}$ は甲状腺, 副甲状腺摘出 (TPTX) 動物の十二指腸ての Ca 輸送と骨組 織からの骨塩動員を 100 単位の $25-\mathrm{OH}-\mathrm{D}_{3}$ 投与の場合よりもはるかに有効に促進したといら結果は $1 \alpha-O H-\mathrm{D}_{3}$ か副甲状腺ホルモン低下泣の治 療薬としても期待されることを実証したものといえる ${ }^{36,66,67) 。 ~}$ 
<smiles>CC12C=CC(=O)C[C@H]1C(O)CC1CCC2C1</smiles>

(Pelc , Kodicek)

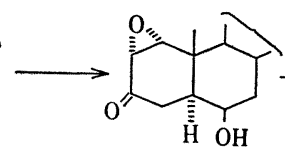

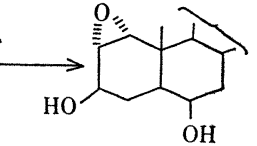

$(+3 \alpha-\mathrm{OH}$ 体 $)$

$\mathrm{AcO}$<smiles>CO[C@H]1CC2=CCC3CCCC2C3(C)[C@@H]2O[C@H]12</smiles>

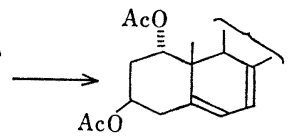

図 15 Fürst らの方法

このようにして1973年末までに少なくとも 6 つのグル 一プが $1 \propto$-hydroxycholesterol の合成を報じたわけであ り，これらのグループはいずれも Wisconsin 大グルー プが同年初期にこれから $1 \alpha-\mathrm{OH}-\mathrm{D}_{3}$ への変換を報じ $た^{64)}$ 時点でいずれも $1 \alpha-\mathrm{OH}-\mathrm{D}_{3}$ の形式的合成を完成し たことになった。しかし，実際に対応する 5,7-dieneに 誘導し光開環により $1 \alpha-\mathrm{OH}-\mathrm{D}_{3}$ までの変換を報告し たグループはわれわれを含め 4 つのグループにすぎな 、64,67 69)。われわれは前述（図 11）したように $1 \alpha-$ hydroxy-7-dehydrocholesterol をただちに光開環して目 的を達したが, 他の 3 つのグループはいずれも前者を diacetate のままで光開環し, その後, 加水分解により 最終物質を得ている。また, Lythgoe らは $\mathrm{D}_{3}$ の合成に 対し独自に開発した方法（図 5) を用いて, やはり1973 年に $1 \alpha-\mathrm{OH}-\mathrm{D}_{3}$ の合成に成功している ${ }^{70)}$ (この方法につ いては II-3 で述べる)。

表示した方法を比較してわかるように Wisconsin 大, 東工大および Hoffmann-RaRoche のグループは 1a$\mathrm{OH}$ 基の導入に関していずれも Pelc と Kodicek の方法 を本質的には踏襲しているといえる。いずれにせよ，わ れわれの方法を含めてこれらの $1 \alpha-\mathrm{OH}$-cholesterol を経 る合成法の優劣は $1 \alpha-\mathrm{OH}$-cholesterol の合成法自身の 問題となるわけで, この点で比較した場合その収率と行 程数*15)のいずれで判定しても Barton 法が最もすぐれ ているといえよう。

\section{1a-OH-cholesterol を経ない cholesterol か} らの部分合成法 II-1 で紹介した $1 \alpha-\mathrm{OH}-\mathrm{D}_{3}$ の合成 はいずれも $1 \alpha-\mathrm{OH}$-cholesterol をその共通の合成中間 体としている。しかしこの方法は次の二つの難点をもっ ている:

（i）この物質から $1 \alpha-\mathrm{OH}-\mathrm{D}_{3}$ を得るためには，まず これを 1 $\alpha-\mathrm{OH}-7-$ dehydrocholesterol に変換しなけ ればならない。そしてその際，アシル化， $\mathrm{Br}$ 化，

*15）東医歯大の旧報（図11）と Barton 法は行程数は同じてあるが，わ れわれの方法の収率は Barton 法の 1/4 1/5 にすきない。 $1 \propto-\mathrm{OH}-\mathrm{D}_{3}$

$-\mathrm{HBr}$ 化および加水分解によ る $\mathrm{OH}$ 基の複元*16)の四行程 が必須となる。

(ii）少なくともわれわれの実 験結果からは, $1 \alpha-\mathrm{OH}-\mathrm{cho}$ lesterol からの $1 \alpha-\mathrm{OH}-7-$ dehydrocholesterol の通算収 率は約 $20 \%$ にすぎず*17), 対 応する cholesterol から 7dehydrocholesterol のそれ

（40～50\%）と比較してかなり低い。

われわれは1973年 5 月前述した方法 (図11, これ以後 旧法と呼ぶ）で $1 \alpha-\mathrm{OH}-\mathrm{D}_{3}$ を合成した時点から，ただ ちにこの久点を除くため $1 \alpha-\mathrm{OH}$-cholesterol を経ない cholesterol からの別途部分合成を企画し, 旧法による生 理および臨床試験のための試料の補給と平行して実験を 開始した。

この方法は 1,4,6-trien-3-one を 1,5,7-trien-3-one

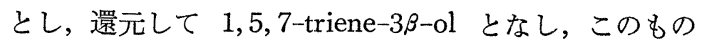
を選択的に 1 位で水和してただちに $1 \alpha$-hydroxy-7-dehydrocholesterol を得ようといらものであり，われわれ の旧法の当然の展開といえた。

前述したように Kruger は 19-nor および 19-hydroxy steroidal-4,6-dien-3-one から対応する 5,7-diene 体を 得ていた ${ }^{52)}$ のでこルートの成功の可能性はかなり高い ものと予想できた。

われわれは旧法の知見に基いてまず deconjugation お よびそれに次ぐ還元反応の条件を種々吟味した結果，ま す 1,5,7-trien-3 $\beta$-ol の合成に成功した。このルートの 隘路は中間体の 1,5,7-trien-3-one の異常な不安定性に あったが，この中間体を単離精製することなく，ただち に $\mathrm{Ca}\left(\mathrm{BH}_{4}\right)_{2}$ で還元し約 $25 \%$ の収率で対応する $1,5,7-$ trien-3 $\beta$-ol を得ることに成功した。この場合，還元剂 として $\mathrm{NaBH}_{4}$ を使用した場合には条件の如何にかかわ らず目的物は得られず，生成物は heteroannular diene の UV 吸収を示す mixture にすぎなかった。われわれ

*16） $1 \alpha^{\prime}-\mathrm{OH}-\mathrm{D}_{3}$ を合成する際，この加水分解は光開環の後てあっても かまわない。

*17）われわれはこの低収率の原因の 1 つか脱 $\mathrm{HBr}$ 化の際に 1 位の OAc 基(axial 配位) 加離脱するためと考えている。しかしこの反応の際

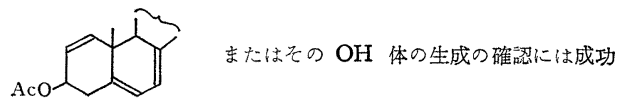

していない。も51つの可能性としては OAc 基(axial 配位)の 加水分解が起りにくいためとも考えられる。Barton らは $1 \alpha-$ hydroxy-cholesterol か. 5 1 $1 \alpha$-hydroxy-7-dehydrocholesterol 1,3-diacetate まての通算収率を36\%と報告している ${ }^{68)}$ 。 


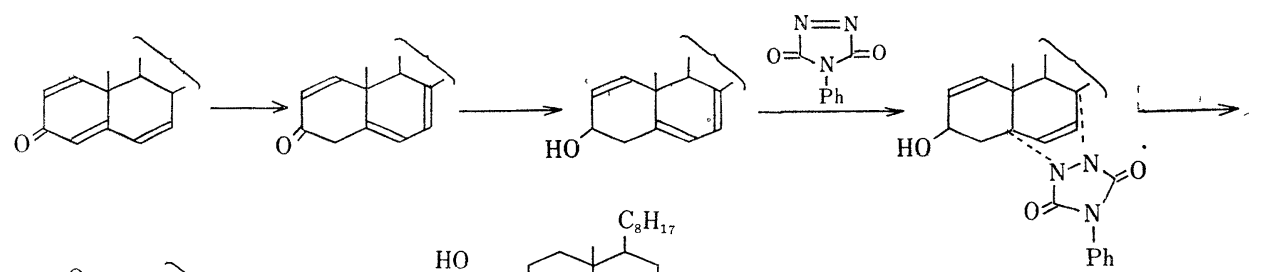

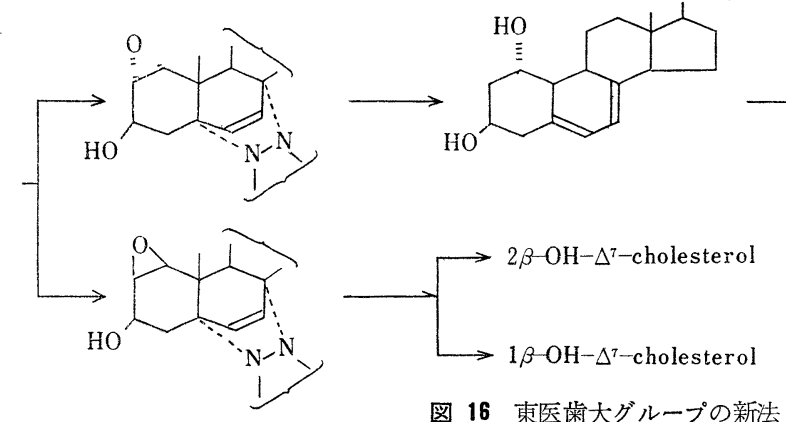

図 16 東医歯大グループの新法 (1974)

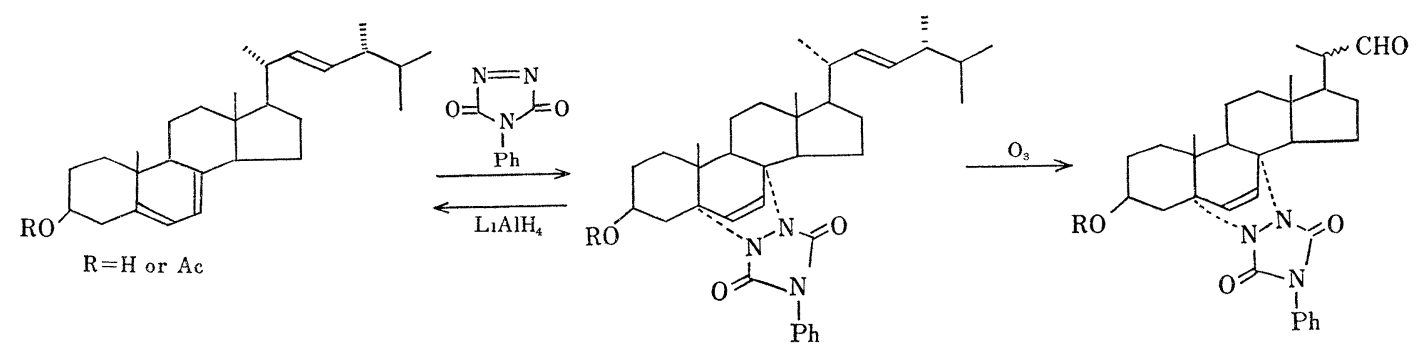

図 17 Barton, Shioiri らの ergosterol と 4-phenyl-1,2,4-triazolin-3,5-dione の cyclic adduct の反応例

は少量のアルカリにより 1,5,7-trien-3-one が一瞬に分 解することを確めたので $\mathrm{NaBH}_{4}$ による還元が目的物を 与えない理由もその塩基性のためと考えている。これに 対し $\mathrm{Ca}\left(\mathrm{BH}_{4}\right)_{2}$ 法泳ぼ中性であり ${ }^{73)}$ しかもその溶解度が 高いため非常に低温下で還元反応を行ならことができる わけである。このようにして原料 trienone より中間体 を分離精製することなく cholesta-1, 5, 7-trien-3 $\beta$-ol が 合成できたわけであるが，このものの水和反応を旧法に 準じ hydroboration およびそれに次ぐ酸化反応により行 なったが，種々の生成物を生じ目的物の收率は数\%に過 ぎなかった。

そこで, 1971年 Barton, Shiorri ら ${ }^{74)}$ にって報告さ れていたジェン基の保護基としての 4-フェニル-1, 2, 4トリアゾリン-3,5-ジオンの使用により 図16に示すコー スにより当初のスキームを完成すをことができた ${ }^{75)}$ 。

Barton, Shioiri ら注図 17 に示すように ergosterol とこの試薬から 1,4-付加体を作りこの付加体が $\mathrm{LiAlH}_{4}$ によって再び ergosterol を生成すること, そしてこの 両反応が共にきわめて高い収率で進行することを明らか にしたばかりか, この付加体により保護された B環の不
飽和系が一般の酸化剤に対し不活性であることを明らか にしていた ${ }^{74)}$ 。

実際の反応においては 1, 4,6-trien-3-one を前述のよ うに deconjugation および還元に付し得られた生成物を そのまま $\mathrm{CHCl}_{3}$ 中で 4-phenyl-1, 2, 4-triazoline-3, 5dione を加えて目的物のみ選択的に 1,4-付加体として からカラムクロマトで分離する。したがってこの反応は 実際には一行程といらことができ，原料からの通算収率 も約 30\% にあげることができた。この付加体を次に $m$-Cl-Ph-COOOH で酸化し, $\alpha$-と $\beta$-monoepoxide と なし，30\%の収率で得られる前者をさらに $\mathrm{LiAlH}_{4}$ で還 元して 1 $\alpha$-hydroxy-7-dehydrocholesterol を得た ${ }^{75)}$ 。

この方法はII-1 に示したいずれの方法よりも行程 数が短くその点で特色のある方法であると自負してい る*18)。けれども $1 \alpha-\mathrm{OH}-\mathrm{D}_{3}$ の合成に用いた場合, そ の收率の点では未だわずかではあるが Barton 法に及ば ない。しかし図18に示すようにこの方法が androstandienedione のエチレンケタールからその保護基をもった

*18）この方法で $1 \alpha-\mathrm{OH}-\mathrm{D}_{8}$ を合成する場合，どの過程にも $\mathrm{OH}$ 基の 保模を必要としない。 


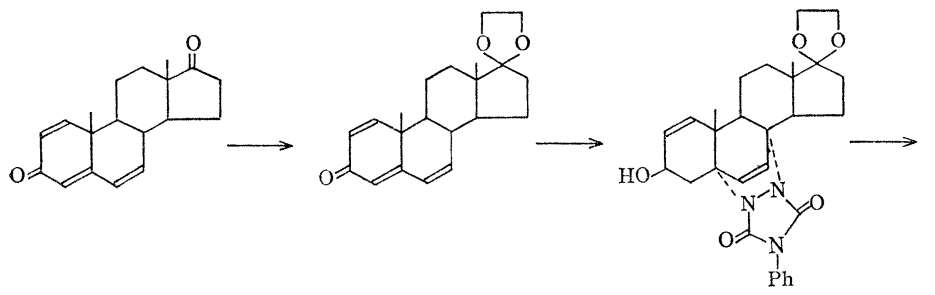

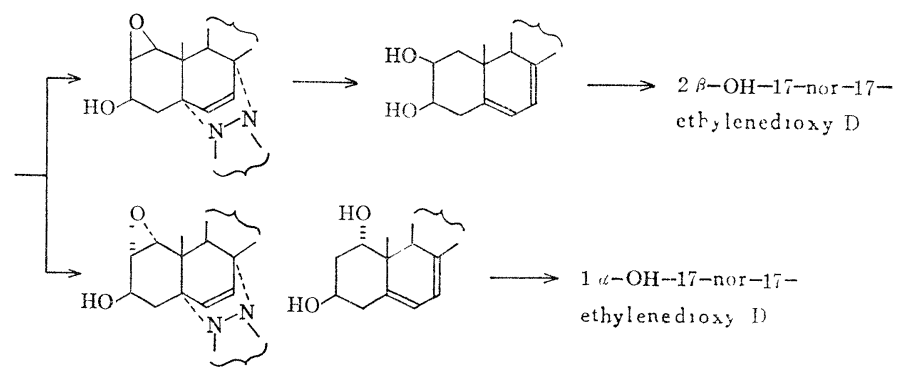

図 18 Hydroxy-17-nor-17-ethylenedioxy D 類の合成に対する東医 歯大グループ新法の応用例 (1974)
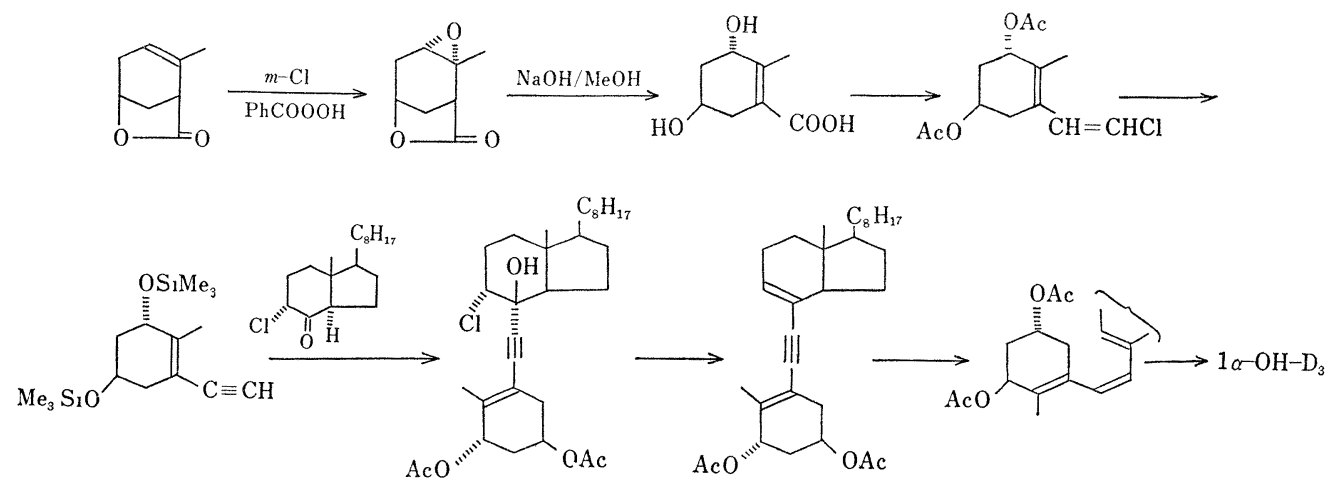

図 19 Lythgoe グループひ $1 \alpha-\mathrm{OH}-\mathrm{D}_{3}$ の全合成ルート (1973)

まま対応する 17-nor-17-keto-D の合成にも全く同様に 応用できる76)ことからもわかるよらに，この行程のすべ ての段階に酸または pyrolysis の条件を使用しない点も 本法の大きな特色としてあげることができる。

3. $1 \boldsymbol{\alpha}-\mathrm{OH}-\mathrm{D}_{3}$ の全合成 前述したように光化学 反応を使用しないきわめてユニークな $\mathrm{D}_{3}$ の全合成法を 確立した Lythgoe らはその方法を応用して 1973 年に $1 \alpha-\mathrm{OH}-\mathrm{D}_{3}$ の全合成に成功した ${ }^{70)}$ 。彼らの方法を 図19 に示す。この方法は $1 \alpha-\mathrm{OH}-\mathrm{D}_{3}$ に限定すれば，明らか に製造的には cholesterol からの変換には及ばないが, 将来生物試験を目的とする各種関連アナログの合成には 大きな力を発揮する可能性を内臟している。

\section{1 $\alpha, 25-(\mathrm{OH})_{2}-\mathrm{D}_{3}$ ならびにその他の $\mathrm{D}_{3}$ の代謝産物とその関連化合物の合成}

1. 25-OH-D の合成研究 1969年以前の $\mathrm{D}_{3}$ の代
謝の研究により，その活性化はまず肝により $25-\mathrm{OH}-\mathrm{D}_{3}$ となることが判明した ${ }^{1 \sim 3) 。}$ そしてこの $25-\mathrm{OH}-\mathrm{D}_{3}$ の生 理作用はビタミン $\mathrm{D}_{3}$ 自身のそれよりもかなり早く発現 することがわかり，その効果も強いことが確められた。 この時点で, $25-\mathrm{OH}-\mathrm{D}_{3}$ が活性代謝産物の本体ではない かと考えられた時期（1967～1969年）があり，当然本化 合物の活発な合成研究が行なわれ，1969年に三つのグル ープによりその合成が完成された。

まず, Blunt ら (Wisconsin 大グループ) は cholestenyl acetate の dibromide をクロム酸酸化した後, 脱ブ ロム化して得られる $3 \beta$-hydroxy-27-norcholest-5-ene25-one-3-acetate を原料とし 図 20 に示す二つの経路で 25-OH-D ても脱 $\mathrm{HBr}$ 化の際に trimethyl phosphite をむちいて いる。これに対して Halkers らはこの step で $s$-collidine を用いて同様の合成を行なっている77)。 


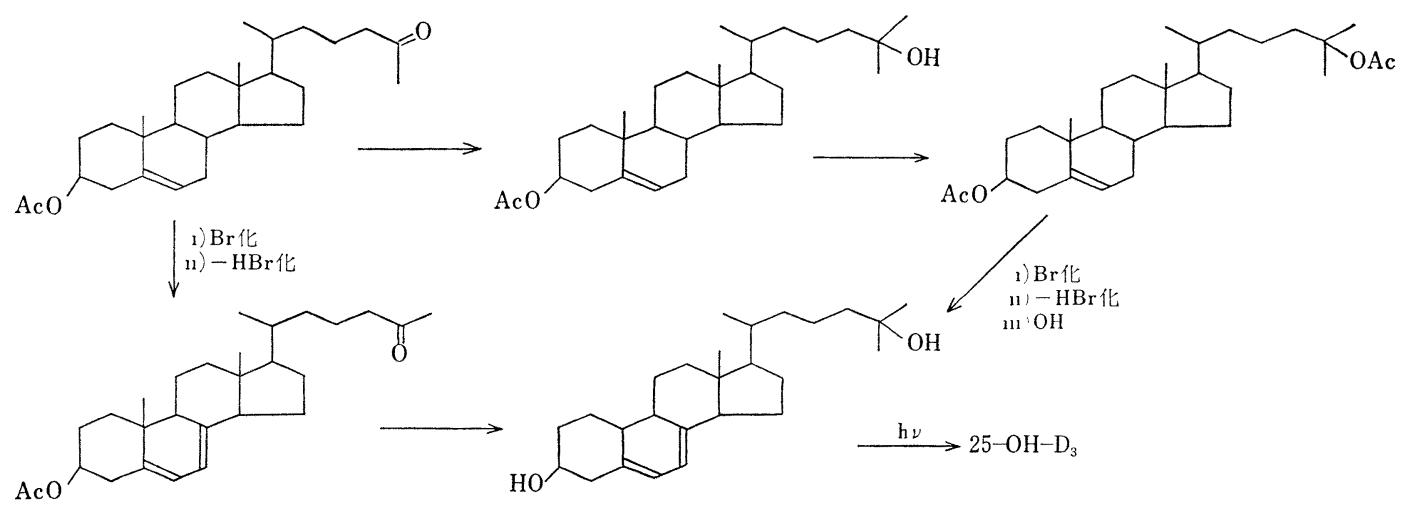

図 20 Bluntら および Halkes らによる $25-\mathrm{OH}-\mathrm{D}_{3}$ の合成

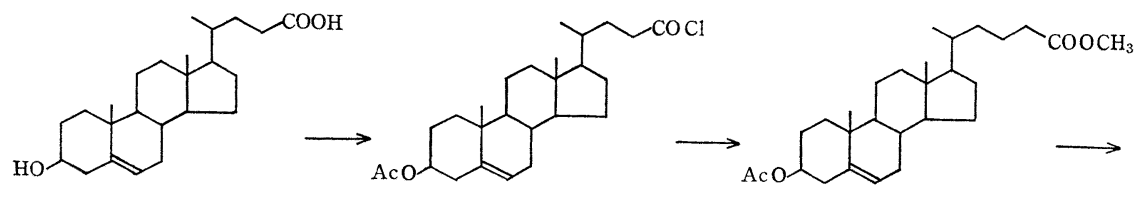<smiles>CCCCCC(C)C1CCC2C3=CC=C4CC(OC(C)=O)CCC4C3CCC21CCC(C)CCCC(C)(O)CCCC(C)(C)O</smiles>

図 21 Campbell らの合成法

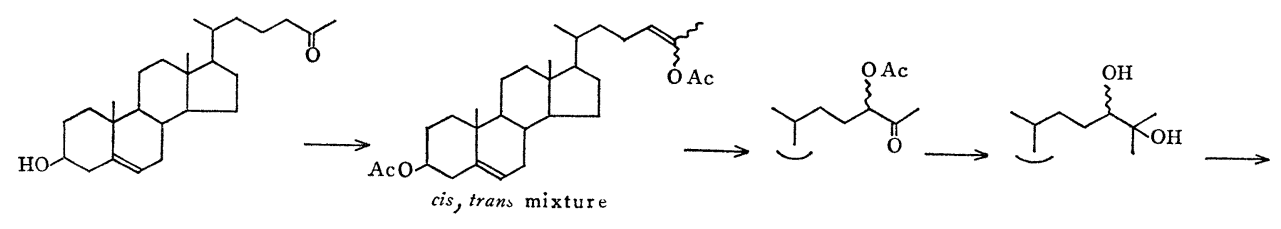

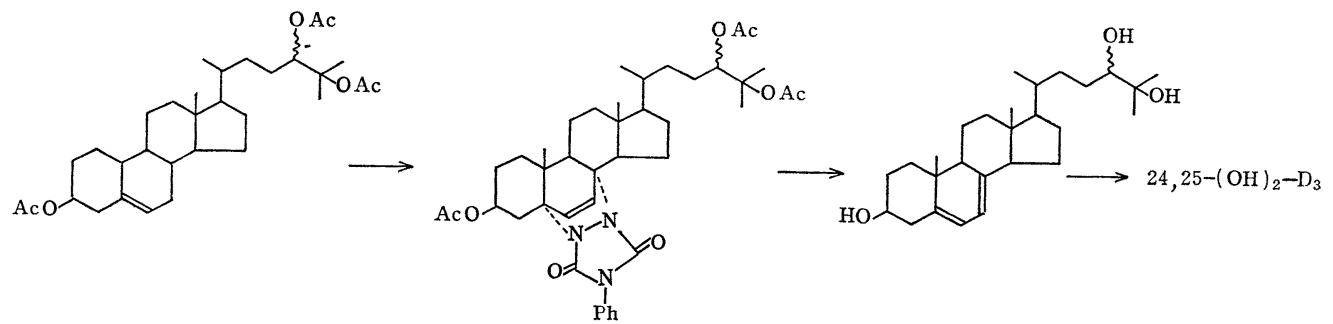

図 22 Wisconsin 大グループの $24,25-(\mathrm{OH})_{2}-\mathrm{D}_{3}$ の合成ルート

一方, Campbell らは 3 $\beta$-hydroxychol-5-enic acid を 原料として 図 21 に示す方法で 25-OH-D $た^{78)}$ 。ごく最近 Hoffmann-LaRoche のグループは stigmasterol ${ }^{79}$ や pregnenolone ${ }^{80)}$ を原料としての $25-\mathrm{OH}-$ cholesterol の合成を報告している。

前述のように 1970年から 1971 年にかけて 25-OH-D よりも polar な metabolite が活性 $\mathrm{D}_{3}$ の本体であるこ
とが判明し $, 1 \alpha, 25-(\mathrm{OH})_{2}-\mathrm{D}_{3}, 24,25-(\mathrm{OH})_{2}-\mathrm{D}_{3}, 25$, $26-(\mathrm{OH})_{2}-\mathrm{D}_{3}$ などの代謝産物の構造が相次いで決定さ れた。活性代謝産物の本体である $1 \alpha, 25-(\mathrm{OH})_{2}-\mathrm{D}_{3}$ の

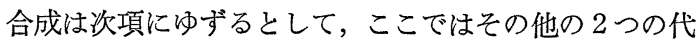
謝産物の合成研究を紹介する。

1973年に H.-Y. Lam ら (Wisconsin 大グループ)は 3 $\beta$-hydroxy-27-norcholest-5-ene-25-one 3-acetate を原 
料として 図 22 に示すルートで $24,25-(\mathrm{OH})_{2}-\mathrm{D}_{3}$ の合 成に成功した ${ }^{811}$ 。この際，彼らはまず $24,25-(\mathrm{OH})_{2}$ cholesterol を合成し，これを $\mathrm{Br}$ 化，脱 $\mathrm{HBr}$ 化によ り対応する 5,7-diene 体 (pro-D) に導いているが，こ の三行程の收率は $14 \%$ といら低收率であると記載され ている。

東工大グループは desmosterol acetate から 25-OHcholesterol を上述の方法のいずれに比べてもはるかによ 、通算收率で得ることに成功 し ${ }^{82)}$ ，あわせて 24,25 $(\mathrm{OH})_{2}$-cholesterol と $25,26-(\mathrm{OH})_{2}$-cholesterol をも合 成した ${ }^{83}$ 。彼らの方法を図 23 亿示す。当然，前二者の 合成は $25-\mathrm{OH}-\mathrm{D}_{3}$ 扩よび $24,25-(\mathrm{OH})_{2}-\mathrm{D}_{3}$ の形式的合 成（formal synthesis）となるわけである。ごく最近,
$25,26-(\mathrm{OH})_{2}-\mathrm{D}_{3}$ の合成が Kodicek らにより報告され $\star^{84)}$ 。

2. $1 \alpha, 25-(\mathbf{O H})_{2}-\mathbf{D}_{3}$ の合成 $\mathrm{D}_{3}$ の活性代謝産物 の本体である $1 \alpha, 25-(\mathrm{OH})_{2}-\mathrm{D}_{3}$ の合成には現在 4 つの グループが成功している。最初の合成は 1972 年に Wisconsin 大のグループによってなされた。すなわち，

Semmler らは 図 24 に示すように $i$-homocholanic acid methylether から出発して21行程でこの化合物の合成に 成功した ${ }^{19}$ 。この合成は行程数が多く，収率の記載もな くそれ程良いとは思えない。しかしこのルートを短時日 に完成した熱意と努力には感嘆の他はない。

彼らの合成は $1 \alpha, 25-(\mathrm{OH})_{2}$-cholesterol を中間体とし ていたのでこの時点でこの物質の合成が $1 \alpha, 25-(\mathrm{OH})_{2}$ -

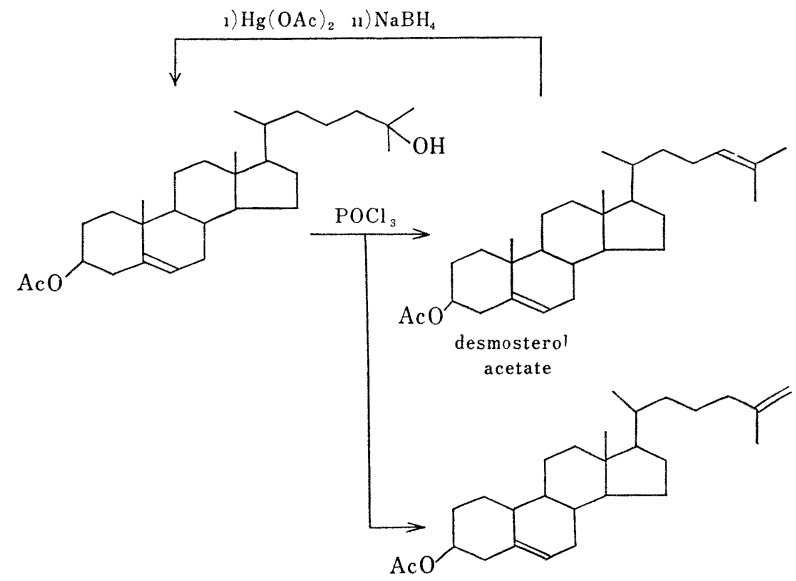

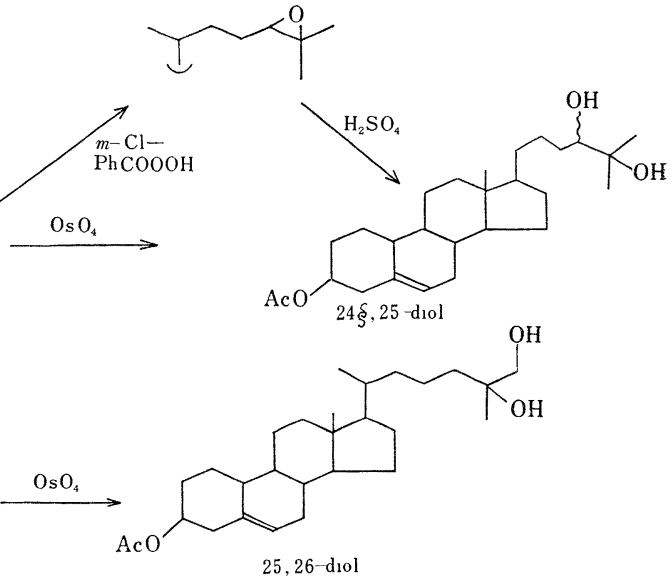

図 23 東工大グループの desmosterol を原料とする側銧水酸化 cholesterol 類の合成ルート
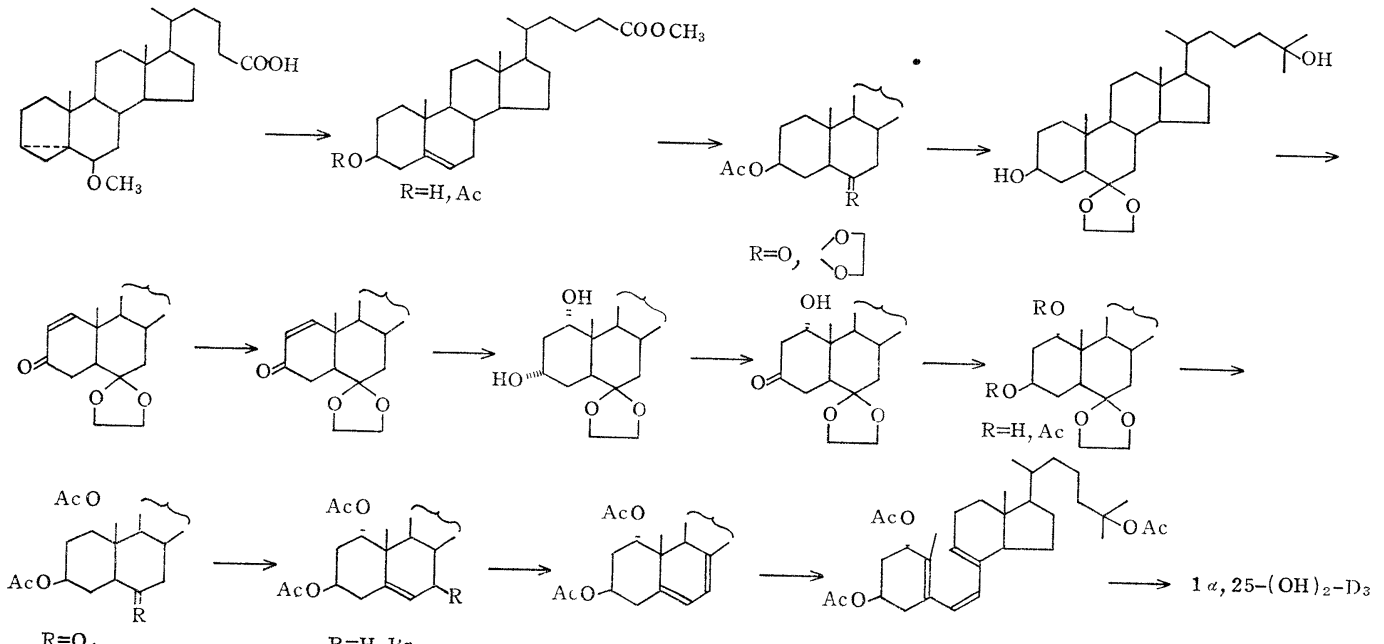

$\mathrm{R}=\mathrm{O}$, $\mathrm{R}=\mathrm{H}, \mathrm{Br}$

$=\mathrm{H}, \beta-\mathrm{OH}$

図 24 Wisconsin 大グループの $1 \alpha, 25-(\mathrm{OH})_{2}-\mathrm{D}_{3}$ の合成ルート 


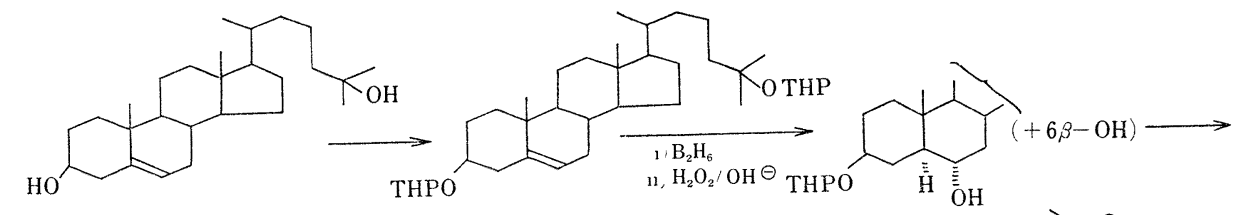

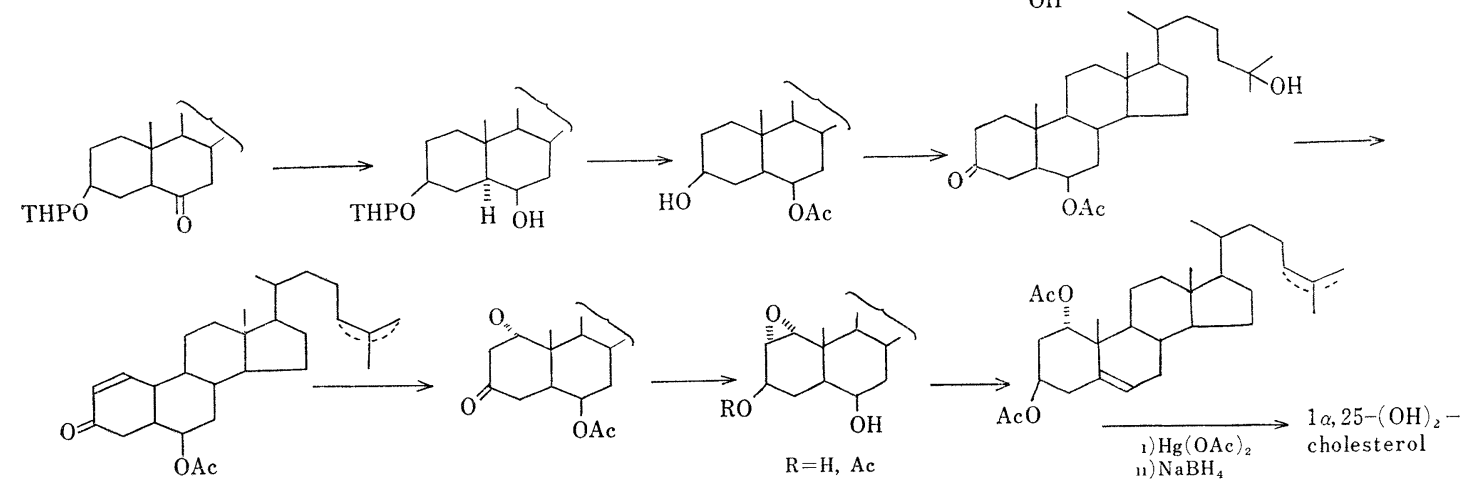

图 25 東工大グループの $1 \alpha, 25-(\mathrm{OH})_{2}-\mathrm{D}_{3}$ の合成法
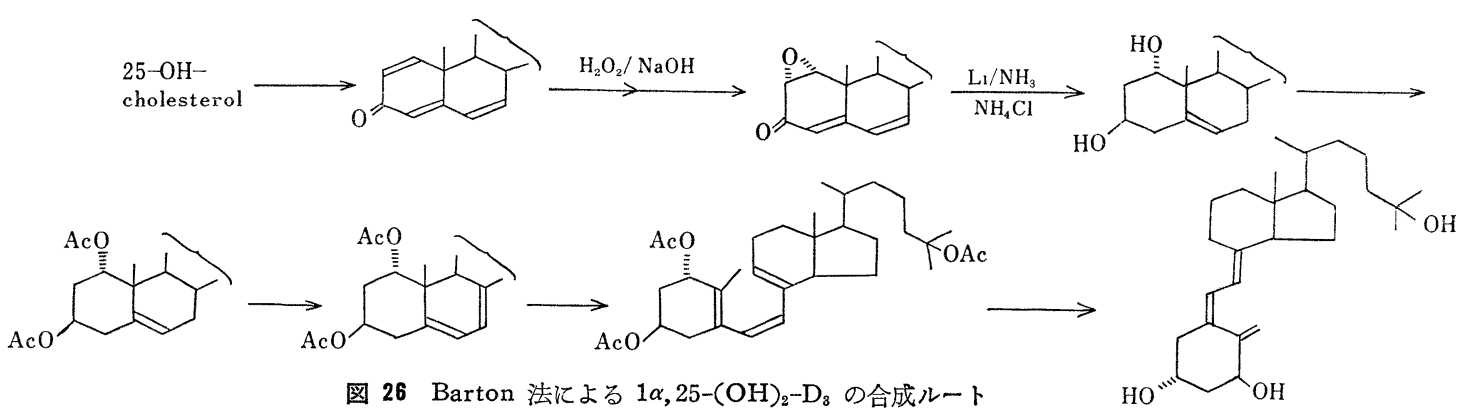

$\mathrm{D}_{3}$ 自身の formal な合成を意味することとなったわけ である。東工大グループは 25-OH-cholesterol を原料 としすでに彼らが 1 $10-\mathrm{OH}$-cholesterol の合成にもちい た方法 (図12)によりこのものを合成した ${ }^{20)}$ このルー トを図 25 に示す。

さらに1973年後半には東工大・帝人グループはBarton 法を応用し，この dihydroxycholesterol の合成ステッ プをいちじるしく短縮することおよび fucosterol から 25-OH-cholesterol をもっとも効率よく合成するルート を確立することに成功した ${ }^{22)}$ 。1974年初め Barton らは 彼らの方法で得た $1 \alpha, 25-(\mathrm{OH})_{2}$-cholesterol から対応す る $1 \propto, 25-(\mathrm{OH})_{2}-\mathrm{D}_{3}$ を合成し，これをはじめて結晶と して単離することに成功した ${ }^{21)}$ 。ごく最近, HoffmannLaRoche のグループは, 1 $1 \alpha, 25-(\mathrm{OH})_{2}$-cholesterol を合 成し，就せてその X-ray 解析を報告している ${ }^{85) 。 ~}$

3. 代謝産物以外のDのアナログの合成 現在この 例に属するものは非常に多く合成されているが，ここで は tachysterol や trans-D 類をのぞきD骨格 (5, 6-cis 構造をもつ)をもつものだけについて紹介する。
Bontekoe らは 図 27 に示す 5 種の側鎖の加工された Dアナログを合成しているがこれらはいずれも D作用を 発現しな( ${ }^{86) 。}$

Crump, Pelc らは 22S-OH-D 4 を ergosterol acetate から合成したが，やはり作用がなかったことを報告して いる ${ }^{87 \text { 。 }}$

われわれる現在までにこの螌畴にはいる六種の $\mathrm{A}$ 環水 酸化 $\mathrm{D}$ 類の合成に成功しているので，以下これらの合成 とそのいくつかについて行なった予報的な生理テストの 結果について述べる。

まず，図11 の方法で得られる $2 \alpha-\mathrm{OH}-$ cholesterol か ら常法の 4 行程により 7-dehydro 体となし, 次にこれ を光開環することによって $2 \alpha-\mathrm{OH}-\mathrm{D}_{3}$ を合成した ${ }^{88)}$ 。 この場合 2 $\alpha$-OH-cholesterol からの 7-dehydro 体の収 率は約 $40 \%$ と $1 \alpha-\mathrm{OH}$ 体のそ机比し高く, ほぼ cholesterol acetate からの 7-dehydrocholesterol の収率と 変らない222。この結果は前述した $1 \alpha-\mathrm{OH}$-cholesterol の 対応する 7-dehydro 体への変換収率がほぼ 20\%にすぎ なかったことと比較して興味ぶかい。この理由の一つは 
<smiles>[R]C1CCCC2/C(=C/C=C3/C[C@H](C)CCC3=C)CCCC12</smiles>

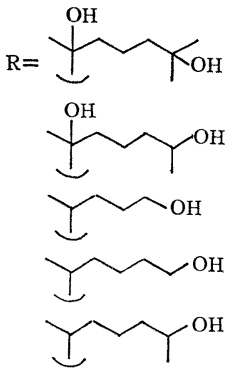

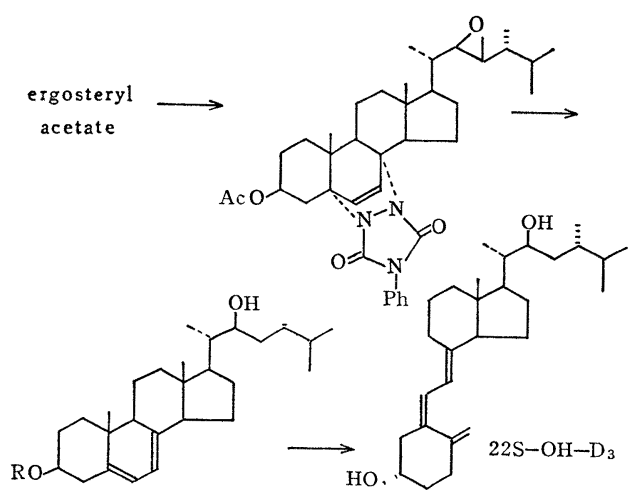

図 27 側鎖の酸化された非天然型のDアナログ

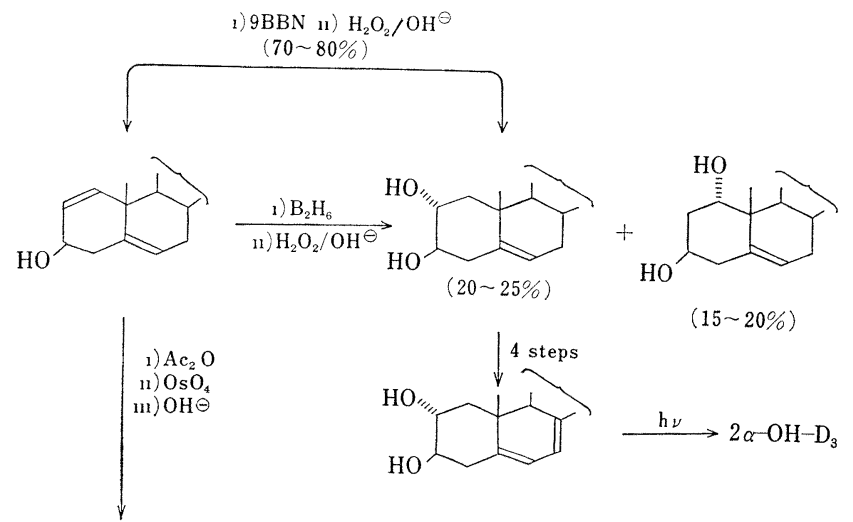

ず $2 \alpha-\mathrm{OH}$ 体のみが $70 \sim 80 \%$ の収率でほぼ選 択的に得られることを見出した ${ }^{88)}$ 。これらの結 果を図 28 に示す。

須田，佐々木らの生化学グループの予報的な 生理テストによると本品は非常に弱いながらも 正常ならびに腎摘ラットにおいて共に小腸から の Ca イオンの吸収を促進することが明らかに されている ${ }^{88)}$ 。この結果はその $2 \alpha-\mathrm{OH}$ 基が生 体酵素系において $1 \alpha-\mathrm{OH}$ 基の機能を多少とも mimicするためではないかと考えられるが，こ の点に関してはより詳細な生理テストの結果を 待ちたい。われわれはごく最近図 28 下段に示 すように $\Delta^{1}$-cholesterol を $\mathrm{OsO}_{4}$ で酸化する ことよって得られる $1 \alpha, 2 \alpha-(\mathrm{OH})_{2}$-cholesterol から出発して常法により $1 \alpha, 2 \alpha-(\mathrm{OH})_{2}-\mathrm{D}_{3}$ の 合成にも成功した ${ }^{* 19}$ 。一方，新法（図 16）に

図 $282 \alpha-\mathrm{OH}-\mathrm{D}_{3}$ および $1 \alpha, 2 \alpha-(\mathrm{OH})_{2}-\mathrm{D}_{3}$ の合成法 $2 \alpha-\mathrm{OH}$ 体に拈けるとの $\mathrm{OH}$ 基が $\mathrm{A}$ 環に対し equatorial 配位をもつためと考えられる。われわれはさらに cholesta-1,5-dien-3 $\beta$-ol $の$ hydroboration を diborane $の$ 代 りに $9 \mathrm{BBN}^{89}$ で行ならと対応する $1 \propto-\mathrm{OH}$ 体は得られ
よって得られる $2 \beta-\mathrm{OH}-7-$ dehydrocholesterol からも光 照射によって $2 \beta-\mathrm{OH}-\mathrm{D}_{3}$ が合成できた ${ }^{90)}$ 。

さらに，東医歯大，盛進グループは協同して図18の方 法で得た二つの $\mathrm{OH}$ 化された 17-nor-17-ethylendioxy

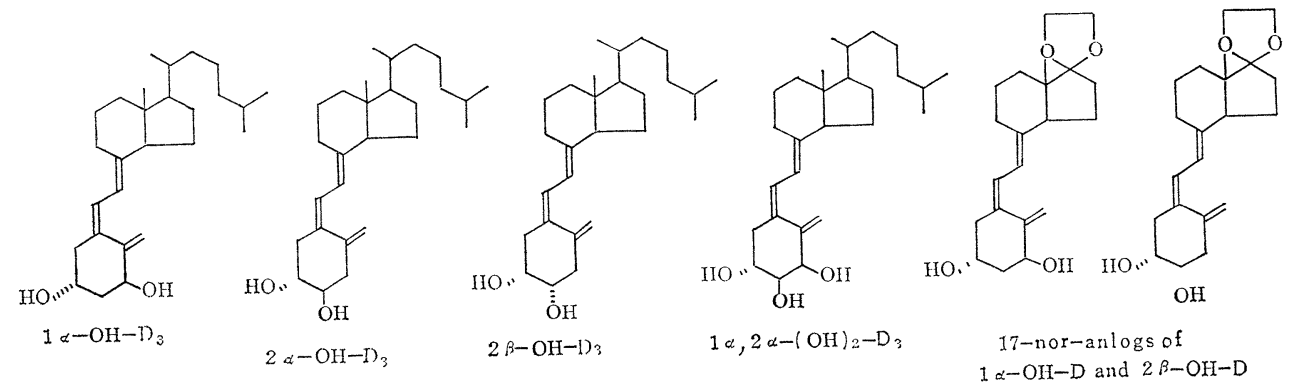

図 $29 \mathrm{~A}$ 環の水酸化されたDTナログ

*19）本品の生理試験は須田, 佐々木らの生化ケループにより行なわれつつある。本品の合成およひ生理作用にらいては1974年 11月の“反応と合成の進 歩シンポシウムーライフサイエンスを志向した理論, 反応および合成”て発表の予定である年。 


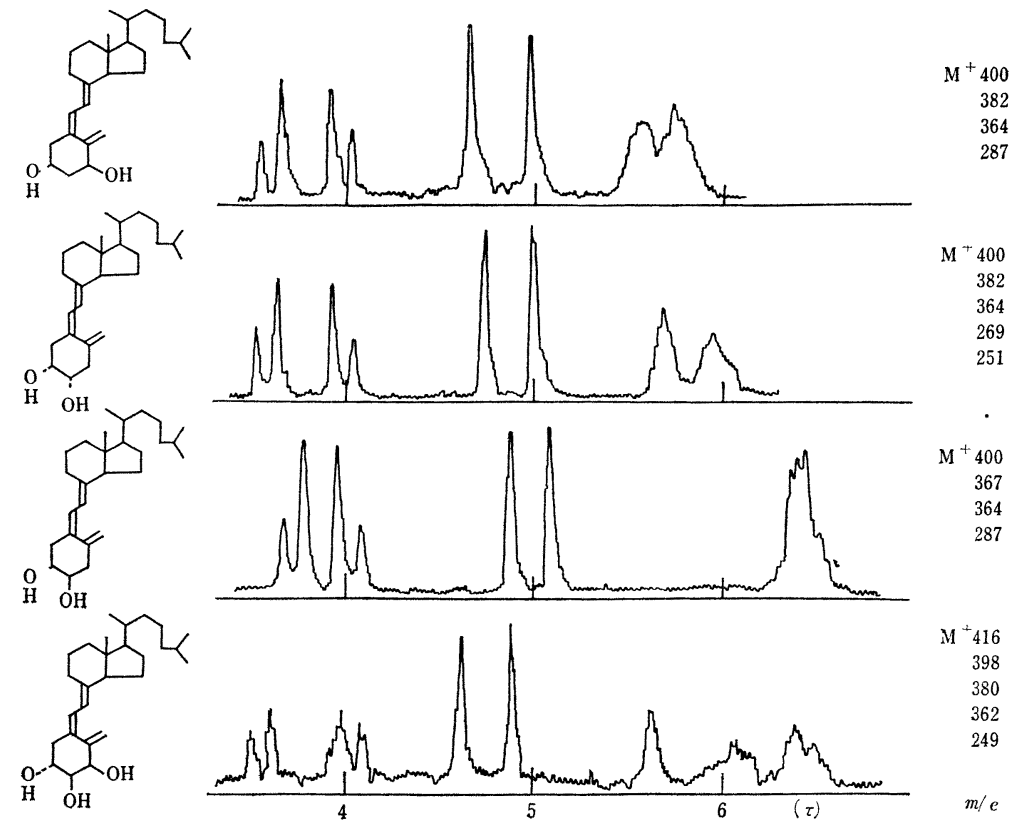

図 $301 \alpha-, 2 \beta-, 2 \alpha-(\mathrm{OH})-\mathrm{D}_{3}$ および $1 \alpha, 2 \alpha-(\mathrm{OH})_{2}-\mathrm{D}_{3}$ の $\mathrm{nmr}\left(\mathrm{CDCl}_{3}\right)$ と mass スペクトル

androsta-5,7-dien-3 $\beta$-ol からも光開環により 1 $\alpha$-およ

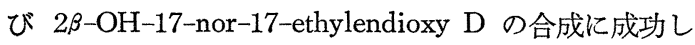
ている ${ }^{91)}$ ここにおいてもやはり $1 \alpha$-体に弱いけれども 小腸からの $\mathrm{Ca}$ 吸收促進作用が見出されている ${ }^{91)}$ 。け れどもその効果は $1 \alpha-\mathrm{OH}-\mathrm{D}_{3}$ にくらべて約 $1 / 200$ であ り，17位の側鎖がD作用発現に必要であるといら定説を くつがえすよりむしろ裏づけている。図 29 にこれらの アナログの構造を，また 図 30 にそのいくつかの $\mathrm{nmr}$ スペクトルを $1 \alpha-\mathrm{OH}-\mathrm{D}_{3}$ と対比して表示する。

いずれにせよこれらのジェン類の pre-D を経るDへ の変換収率は 7-dehydrocholesterol からの $\mathrm{D}_{3}$ へのそ れとあまり変らないことから，これらの二つの step に 対しては pro-D における $1 \alpha-\mathrm{OH}$ 基の存在は以後の 反応になんの障害にもならないといえる。ごく最近， DeLuca らおよび Norman らはそれぞれ別個に 3-deoxy-1 $1 \alpha-\mathrm{OH}-\mathrm{D}_{3}$ の合成に成功し, これが $1 \alpha-\mathrm{OH}-\mathrm{D}_{3}$ 様 の生理作用を示すことを明らかにした ${ }^{93)}$ 。

\section{IV. 標識された $\mathbf{D}_{3}$ 類の合成}

vitamin $\mathrm{D}_{2}$ または $\mathrm{D}_{3}$ の一単位 (1U) は $0.025 \mu \mathrm{g}$ （r）という少量であり体重 $100 ２ 00 \mathrm{~g}$ のラットやマウ スに対する生理的な vitamin D 量は 4 100 IU (0.1〜 $2.5 \mu \mathrm{g}) /$ day である。したがって, 活性ビタミンDの代 謝実験においてはかなり比放射能の高い放射性 vitamin
D が用いられた。

いままで, Wisconsin 大グルー プは ${ }^{14} \mathrm{C}$-vitamin $\quad \mathrm{D}_{2} \quad(30,000$ $\mathrm{dpm} / \mathrm{IU})^{94)}, \quad 1,2-^{3} \mathrm{H}-\mathrm{D}_{3} \quad(26,000$ $\mathrm{dpm} / \mathrm{IU})^{95)}, 22,23-{ }^{3} \mathrm{H}-\mathrm{D}_{4}(100,000$ $\mathrm{dpm} / \mathrm{IU})^{96)}, 26,27-{ }^{3} \mathrm{H}-25-\mathrm{OH}-\mathrm{D}_{3}$ $(180,000 \mathrm{dpm} / \mathrm{IU}[1,3 \mathrm{ci} / \mathrm{mM}])^{97)}$ などの合成に成功している。

Kodicek ら\& $1 \alpha-{ }^{3} \mathrm{H}-\mathrm{D}_{3}{ }^{98}$ や $4{ }^{-14} \mathrm{C}-\mathrm{D}_{3}{ }^{5,99}$ などの合成に成功し ている。DeLuca や Kodicek ら が前述した $\mathrm{D}_{3}$ の代謝研究に主導 的役割を演じた大きな理由の一つ は彼らがこれらの標識化合物を 有効に使ったことにあるといえ る $^{33 \sim 35)}$ 。

これからも $\left.1 \alpha, 25-(\mathrm{OH})_{2}-\mathrm{D}_{3}{ }^{* 20}\right)$ や $1 \alpha-\mathrm{OH}-\mathrm{D}_{3}$ の代謝研究（臨床 テストを含めて）のためには比放 射能の高いサンプルを合成し生化 学者に供給することも合成化学者 の一つの課題となろう*21)。

\section{V. $\mathbf{D}_{3}$ の代謝産物の合成に利用できる いくつかの最近の知見}

1966 年池川, 津田らは䄑藻類に fucosterol が多量に 含まれていることを見出した ${ }^{101)}$ 。池川・森崎らの東工大 グループはここ数年この fucosterol の利用研究を活発 に行なっているが，最近これを簡単かつ高収率で desmosterol に変換する方法を見出し, 側鎖の水酸化され た $\mathrm{D}_{3}$ 類の合成中間体の製造にまったく新しいルートを 開拓した ${ }^{22,102)}$ 。現在までに報告された fucosterol から desmosterol への変換ルートを 図 31 に示す。

したがって，fucosterol が工業的に大量製造されるな らば， 10 位への水酸基導入法の一層の改良と相まって $1 \alpha, 25-(\mathrm{OH})_{2}-\mathrm{D}_{3}$ の大量合成がより容易になることはう たがいない。

これと関連して Weismann Institute の Mazur らはご く最近図32に示すように $5 \alpha$-cholestanol が $\mathrm{CH}_{3} \mathrm{COOOH}$ 中で光照射することにより比較的よい収率でその 25 位が 水酸化されることを見出している(103)。ステロイドにお いては 3 位の $\mathrm{OH}$ 基を手がかりとして 1,4-dienone や

*20）現在代謝実験に供されている標識 $1 \alpha, 25-(\mathrm{OH})_{2}-\mathrm{D}_{2}$ は上記の標識

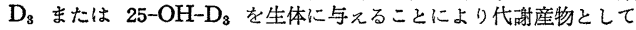
得られたもののみである。

*21）最近, 放射線同位元素標識体のかわりに安定同位元素標識体を臨床 薬理や葲物代謝研究に忘用する方法も発達してきつつある100)。 


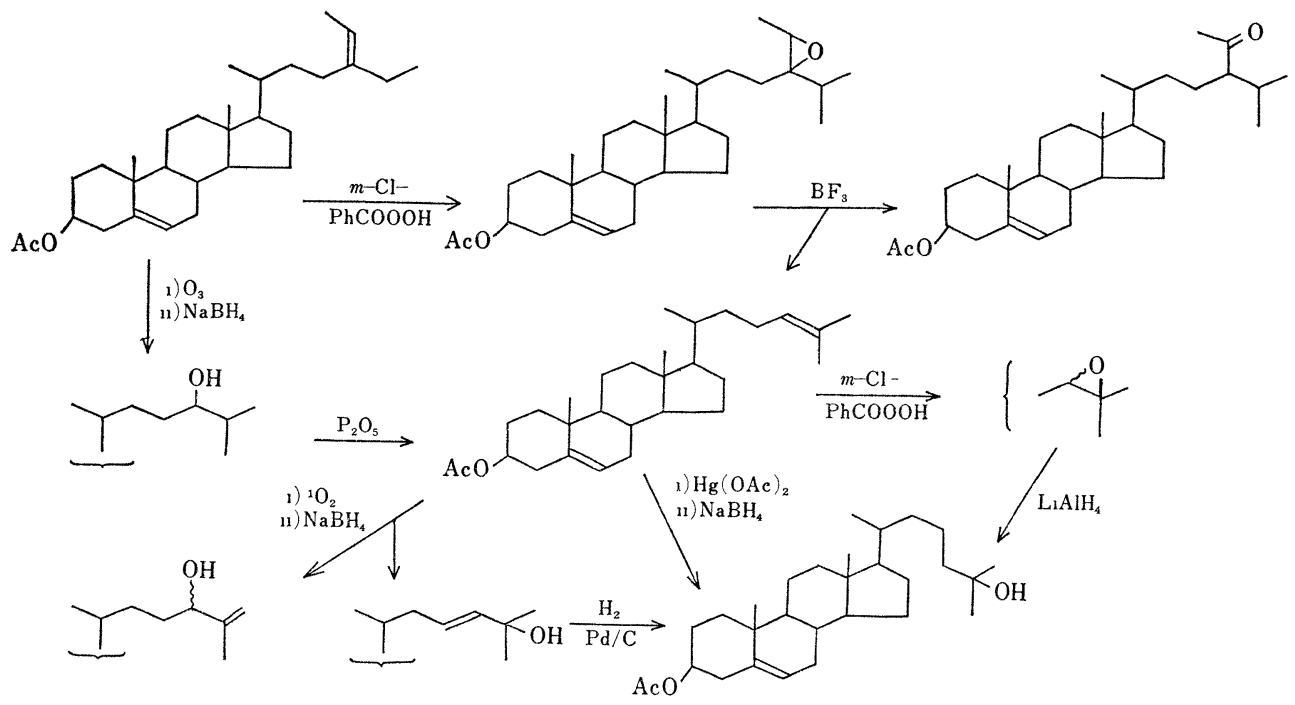

図 31 東工大グループの fucosterol から desmosterol への変換ルート

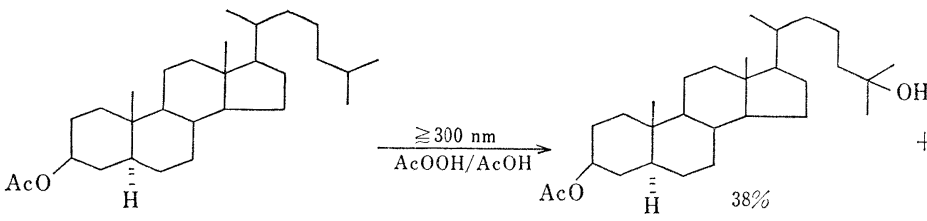<smiles>CC(=O)OC1CCC2(C)C3CCC4(C)C(C(C)CCCC(C)C)CCC4C3CC[C@]2(O)C1</smiles>

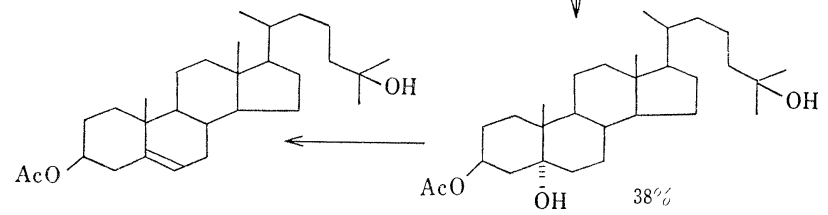

図 32 Weizmann Institute の cholestanol 類の光酸化反応

1, 4,6-trienone に容易に誘導できるので現在開発されて いる 1 $\alpha-\mathrm{OH}$ 化の方法と併用すれば cholesterol からも $1 \alpha, 25-(\mathrm{OH})_{2}-\mathrm{D}_{3}$ が合成できることになる。

ステロイド類の微生物酸化による $1 \alpha$ 位ならびに $1 \beta$ 位の水酸基導大もいくつか報告されている ${ }^{104,105) 。 ま た ~}$ やはり 微生物酸化により cholesterol から androsta1,4-dien-3, 17-dione が高収率で得られている cholesterol 類の側鎖を変えずにその A 環に対しこの種 の修飾を行ならことを目的とした微生物酸化の研究も今 後の課題ではなかろうか。

\section{VI. 今後の合成研究}

現在, 合成的に非常に安価に得られるようになった $1 \alpha-\mathrm{OH}-\mathrm{D}_{3}$ を試験段階ではあるがラットに対して経口 投与した場合, $1 \alpha, 25-(\mathrm{OH})_{2}-\mathrm{D}_{3}$ よりもより有効である
という事実 ${ }^{16,27,107)}$ は合成が安価である点と共に $1 \alpha-\mathrm{OH}-$ $\mathrm{D}_{3}$ の薬剤としての価值を著しく高めたようにみえる。 さらに, $1 \alpha-\mathrm{OH}-\mathrm{D}_{3}$ の静注による臨床試験の結果もす でにいくつか報告されており, 多くの場合, 顕著な治療 効果が認められている107 110)。しかし，これらの事実は 正常代謝産物である $1 \alpha, 25-(\mathrm{OH})_{2}-\mathrm{D}_{3}$ の価值を下げる ことにはならない。

しかし, 非天然物的な $1 \alpha-\mathrm{OH}-\mathrm{D}_{3}$ が $1 \alpha, 25-(\mathrm{OH})_{2}-$ $\mathrm{D}_{3}$ と同程度の活性を示すという事実は合成化学者にと っては非常に大きな知見と思われる。この事実は $\mathrm{D}_{2}$ か $ら \mathrm{D}_{7}$ まで知られている一連の $\mathrm{D}$ 類の $1 \alpha-\mathrm{OH}$ 体をもし合 成できれば，これらがやはり腎不全患者において活性を 有する可能性が高いことを示唆するものだからである。 同じ意味で $1 \alpha$-位に水酸基をもち，側鎖に水酸基をもつ Dアナログの合成は代謝型の側鎖をもつものの合成と共 
に興味があり, 今後も $1 \alpha-\mathrm{OH}$ 基の導入法の改良を含め て, 合成化学者のよい課題と思われる。

薬鼡としてD類，1 $1 \alpha, 25-(\mathrm{OH})_{2}-\mathrm{D}_{3}$ 沈もとよりそれら の合成アナログを適用する場合には図 1 の経路からもわ かるように，それらの化学修飾がまず生体に吸収される 過程(径口の場合)にどら影響するかとか，作用発現の部 位（標的器官）で岕る小腸および骨組織への親和性がど のように変るかも問題とならう。ごく最近, Haussler ら は $\mathrm{D}_{3}, \mathrm{DHT}_{3}, 1 \alpha-\mathrm{OH}-\mathrm{D}_{3}, 25-\mathrm{OH}-\mathrm{D}_{3}, 1 \alpha, 25-(\mathrm{OH})_{2}-$ $\mathrm{D}_{3}$ など と小腸の上皮組織のクロマチンの間の親和性を 比較し， $\mathrm{OH}$ 基が増える程その親和性が著しく増すこと を報告している*22),111)。

\section{VII.おわりに}

DeLuca 教授のもとで $1,25-(\mathrm{OH})_{2}-\mathrm{D}_{3}, 24,25-(\mathrm{OH})_{2}$ $\mathrm{D}_{3}, 25,26-(\mathrm{OH})_{2}-\mathrm{D}_{3}$ なぞの単離とそれらの構造決定を 行なった須田助教授が1971年俙国されたのを機に, 本研 究は同博士の所属する東京医科歯科大学齿学部生化学教 室 (佐々木哲教授) のグループと同大医用器材研究所化 学部 (石川正幸教授) のグループとの協同研究として始 められ今日に至っている。

合成実験の大部分は化学部山田幸子抒よび杉本昭子の 二人によって行なわれた。また新法には江口征夫む協力 した。これらの人々の熱心かつ確実な実験によって，上 述の合成が生み出されたものである。また，これらスタ ッフを本研究にまわしていただき，かつ全般にわたりご 援助，ご協力いただいた石川教授に厚く感謝する。

また，1972年当初本研究を始めるにあたり大量の各種 ステロイド原料を提供下さった盛進製薬の加藤元彦博 士，各種の試薬を提供された第一化学の長谷川賢博士に も厚く感謝したい。17-nor-17-keto-D 類の合成は盛進 製薬の坂本治雄君との協同研究である。また，新法を開 発するに当たり 4-phenyl-1,2,4-triazoline-3,5-dione にまつわる問題点を種々ご教示いただいた東大薬学部塩 入孝之博士にも感謝したい。

生化学に馿染みのうすいわれわれと常に対等に discu一 ssion して下さった佐々木, 須田両博士の熱意, 激励と これら先輩, 友人の好意の結果がこの合成研究であると いえる。

$1 \alpha-\mathrm{OH}-\mathrm{D}_{3}$ は今や大量合成, 臨床試験を含む製剤化 といら新しい段階を迎えている。われわれのグループも 一層拡大されることとならう。

*22）この順序は $1 \alpha-\mathrm{OH}-\mathrm{D}_{3}$ を除けは生理効果とほぼパラレルである点 は興味深い。したがって Haussler らのデータは, $1 \alpha-\mathrm{OH}-\mathrm{D}_{3}$ が まず $1 \alpha, 25-(\mathrm{OH})_{2}-\mathrm{D}_{3}$ に変換してから作用を発現するという可能 性を示唆している。
追記 本総説は 1974 年 6 月末に完成した。また粗原 稿の段階で協同研究者である須田博士に生化学面での内 容のチェックをふくめて通読していただき種々有益かつ 的確な訂正や助言をいただいた。また；本総説は大部分 1974年 6 月の東大薬学部合成系連合セミナーおよび日本 薬学会北海道支部会特別講演におお括著者の講演にもと づいている。

\section{（昭和 49 年 9 月 26 日受理）}

\section{文献}

1) J.W. Blunt, H.F. DeLuca, H.K. Schnoes, Biochem. 73317 (1968)

2) J.W. Blunt, H.F. DeLuca, Brochem. 8671 (1969)

3) T. Suda, H.F. DeLuca, H.K. Schnoes, J.W. Blunt, Brochem. 83515 (1969)

4) M.F. Holick, H.K. Schnoes, H.F. DeLuca, T. Suda, R.J. Cousins, Brochem. 102799 (1971)

5) D.E.M. Lauson, D.R. Fraser, E. Kodicek, H. R. Morris, D.H. Williams, Nature 230228 (1971)

6) M.F. Holick, H.K. Schnoes, H.F. DeLuca, R.W. Gray, I.J. Boyle, T. Suda, Brochem. 11 425 (1972)

7) I.J. Boyle, J.L. Omdahl, R.W. Gray, H.F. DeLuca, J. Biol. Chem. 2484174 (1973)

8) I.J. Boyle, R.W. Gray, H.F. DeLuca, Proc. Nat. Acad. Sci. U.S.A. 682131 (1971)

9) T. Suda, H.F. DeLuca, H.K. Schnoes, Y.. Tanaka, H.F. Holick, Brochem. 94776 (1970)

10) D.R. Fraser, E. Kodicek, Nature 228764 (1970)

11) R.W. Gray, I.T. Boyle, H.F. DeLuca, Science 1721232 (1970)

12) M.R. Haussler, D.W. Boyle, E.T. Littledike, H. Rasmussen, Proc. Nat. Acad. Sci. U.S.A. 68171 (1971)

13) J.L. Omdahl, H.F.Holick, T. Suda, Y. Tanaka, H.F. DeLuca, Biochem. 102935 (1971)

14) M.F. Holick, H.K. Schnoes, H.F. DeLuca, Proc. Nat. Acad. Sci. U.S.A. 68803 (1971)

15) Y. Tanaka, H.F. DeLuca, Arch. Biochem. Biophys. 146574 (1971)

16) Y. Tanaka, H. Frank, H.F. DeLuca, Endoclinology 92417 (1973)

17) J.M. Omdahl, H.F. DeLuca, Physiological Reveews 53352 (1973)

18) R.H. Wasserman, A.N. Taylor, J. Nutrition 103586 (1973)

19) E.J. Semmler, M.F. Holick, H.K. Schnoes, H.F. DeLuca, Tetrahedron Lett. 19724147

20) J. R-Lightbourn, M. Morisaki, N. Ikekawa, Chem. Pharm. Bull. 211854 (1973)

21) D.H.R. Barton, R.H. Hesse, M.M. Pechet, E. 
Rizzardo, Chem. Commun. 1974203

22) M. Morisaki, J. R-Lightbourn, N. Ikekawa, T. Takeshita, Chem. Pharm. Bull. 212568 (1973)

23) S. Sagar, R.L. Estrada, M. Kaye, Arch. Intern. Med. 130768 (1972)

24) T. Suda, R.B. Hallick, H.F. DeLuca, H.K. Schnoes, Biochem. 91651 (1970)

25) M.F. Holick, M. Garabedian, H.F. DeLuca, Biochem. 112715 (1972)

26) M.F. Holick, M. Garabedian, H.F. DeLuca, Science 1761146 (1972)

27）田中洋子, ファルマシア 10319 (1974)

28) A.S. Brickman, J.W. Coburn, A.W. Norman, New Eng. J. Med. 287891 (1972)

29）小林正，化学と生物 1070 (1972)

30) 小林正, ビタミン 47381 (1973)

31）池川信夫，森绮益雄, ファルマシア $10319(1974)$

32) H.F. DeLuca, New Eng. J. Med. 289359 (1973)

33）須田立雄, H.F. DeLuca，蛋白・核酸・酵素 17 176 (1972)

34）須田立雄, ビタミン 45175 (1972)

35）須田立雄, 堀内登, 代謝 1021 (1973)

36）須田立雄, 鈴木ミチ子, 角田佐武郎, 佐々木哲, 内科 321010 (1973)

37）須田立雄, 上田奏編, “腎臟学の進歩” 医学 書 院 (1974)

38）佐々木哲, 須田立雄, 吉木周作, 日本歯科医師会 雑誌 27 22-135 (1974)

39) J.W. Blunt, If.F. DeLuca, H.K. Schnoes, Chem. Commun. 1958801

40) J.W. Blunt, Y. Tanaka, H.F. DeLuca, Proc. Nat. Acad. Sci. U.S.A. 6I 717 (1968)

41) C.Trummel, L.G. Raiz, J.W. Blunt, H.F. DeLuca, Science 1631450 (1969)

42) A. Windaus, M. Deppe, W. Wunderlich, Ann. 533118 (1938); see also, L.F. Fieser, "Steroids. Reinhold N.Y." p. 130 (1959)

43) H.H. Inhoffen, K. Irmscher, H. Hirschfeld, U. Stache, A. Kreuzer, Chem. Ber. 912309 (1958); J. Chem. Soc. 1959385

44) I.T. Harrison, B. Lythgoe, J. Chem. Soc. 1958 837, 847

45) H.H. Inhoffen, Angew. Chem. 72875 (1960)

46) J. Dixon, P.S. Littlewood, B. Lythgoe, A.K. Saksena, Chem. Commun. 1970993

47) T.M. Dowson.J. Dixon, P.S. Littlewood, B. Lythgoe, A.K. Saksena, J. Chem. Soc. (C) 19712960

48) B. Pelc, E. Kodicek, J. Chem. Soc. (C) 1970 1624

49) M.L. Mihailovic, L. Lorence, N. Popov, J. Kolvoda, Helv. Chim. Acta 542281 (1971)

50) J. Ringold, S.K. Malhotra, Tetrahedron Lett. 1962669 ; J. Amer. Chem. Soc. 84 3402(1962)
51) E. Shapiro, L. Weber, E.P. Oliveto, H.L. Herzog, R. Neri, S. Tolksdorf, M. Tanabe, D.F. Crowe, Sterouds 8461 (1966), see also E.L. Shapiro, T. Legatt, L. Weber, E.P. Oliveto, M. Tanabe, D.F. Crowe, Steroids 3 183(1964)

52) G. Kruger, J. Org. Chem. 331750 (1968)

53) R. Wiechert, O. Engelfried, U. Kerb, H.Lauent, H. Muller, G. Schlz, Ber. 99 1118(1966); M. Tanabe, D.F. Crowe, Tetrahedron 232115 (1967)

54）たとえば，野崎一，有機光化学(“化学の領域・増 刊，93”）松浦，野崎編，p. 175 (1970)

55) A. Hajos, O. Fuchs, Acta Chim. Scand. Sci. Hung. 21137 (1959)

56) H.C. Brown, "Hydroboration" Benjamin, N.Y. (1962); H.C. Brown, G. Zweifel, Org. Reactions 131 (1963)

57) S. Wolfe, M. Nussin, Y. Mazur, F. Sondheimer, J. Org. Chem. 241034 (1959)

58) F. Sondheimer, M. Nussim, J. Org. Chem. 26630 (1961)

59）金子主税，山田幸子，杉本昭子，石川正幸，須田 立雄, 佐々木哲, 日本薬学会93年会（1973年 4 月 東京), 要旨集 II-76

60） J. Rubio-Lightbourn，森崎益夫，池川信夫，第 165アメリカ化学会 (1973年 4 月 Dallas)

61) C. Kaneko, S. Yamada, A. Sugimoto, M. Ishikawa, S. Sasaki, T. Suda, Tetrahedron Lett. 19732339

62) C. Kaneko, A. Sugimoto, S. Yamada, M. Ishikawa, S. Sasaki, T. Suda, Chem. Pharm. Bull. 222101 (1974)

63) M. Morisaki, K. Bannai, N. Ikekawa, Chem. Pharm. Bull. 211853 (1973)

64) M.F. Holick, E.J. Semmler, H.K. Schnoes, H.F. DeLuca, Science 180190 (1973)

65）金子主税，山田幸子，杉本昭子，江口征夫，石川 正幸, 須田立雄, 鈴木ミ千子, 角田传武郎, 佐々 木哲，第17回天然有機化合物討論会（1973年，10 月，東京）

66）須田立雄，鈴木ミチ子，角田任武郎，佐々木哲, 金子主税，山田幸子，杉本昭子，江口征夫，石川 正幸，第21回日本内分泌学会東部部会総会（1973 年11月, 東京)

67) C. Kaneko, S. Yamada, A. Sugimoto, Y. Eguchi, M. Ishikawa, T. Suda, M. Suzuki, S. Kakuta, S. Sasaki, Steroids 2375 (1974)

68) D.H.R. Barton, R.H. Hesse, M.M. Pechet, E. Rizzardo, J. Amer. Chem. Soc. 95 2748(1973); See for physiological activity of $1 \alpha-\mathrm{OH}-\mathrm{D}_{3}$; M.R. Haussler, J.E. Zerwech, R.H. Hesse, E. Rizzardo, M.M. Pechet, Proc. Nat. Acad. Sci. U.S.A. 702248 (1973)

69) A. Fürst, L. Labler, W. Meier, K.-H, Pfoertner, Helv. Chim. Acta 561708 (1973)

70) G. Harrison, B. Lythgoe, P.W. Wright, Te- 
trahedron Lett. 19733649

71) M. Garabedian, M.F. Holick, H.F. DeLuca, Proc. Nat. Acad. Sci. U.S.A. 691673 (1972)

72) F. Hunziker, N.L. Mulner, Helv. Chim. Acta 4170 (1958)

73) M. Fieser, L. Fieser, "Reagents for Org. Syn." Vol. 2 p. 57 (1969), John Wiley \& Sons, N.Y.

74) D.H.R. Barton, T. Shioiri, D.A. Widdowson, J. Chem. Soc. (C) 19711968

75）金子主税, 杉本昭子, 江口征夫, 山田幸子, 石川 正幸，佐々木哲，須田立雄，日本薬学会第94年会 (1974 年 4 月，仙台), II-174: C. Kaneko, A. Sugimoto, Y. Eguchi, S. Yamada, M. Ishikawa, S. Sasaki, T. Suda, Tetrahedron 302701 (1974)

76）坂本治雄，杉本昭子，金子主税，日本薬学会第94 年会 (1974年 4 月仙台), 要旨集 II-71:H. Sakamoto, A. Sugimoto, C. Kaneko, Chem. Pharm. Bull. 222903 (1974)

77) S.J. Halkes, N.P. van Vliet, Rec. Trav. Chim. 881080 (1969)

78) J.A. Campbell, D.M. Squires, J.C. Babcock, Steroids 13567 (1969)

79) J.J. Partridge, S. Faber, M.R. Uskokovic, Helv. Chim. Acta 57764 (1974)

80) T.A. Norwid, K.E. Cooney, M.R. Uskokovic, Helv. Chrm. Acta 57771 (1974)

81) H.Y. Lam, H.K. Schnoes, H.F. DeLuca, Biochem. 124851 (1973)

82) M. Morisaki, J. R-Lightbourn, N. Ikekawa, Chem. Pharm. Bull. 21457 (1973)

83) M. Seki, J. R-Lightbourn, M. Morisaki, N. Ikekawa, Chem. Pharm. Bull. 212783 (1973)

84) J. Redel, P. Bell, F. Delbarre, E. Kodicek, C.R. Acad. Sc. Paris, t. 276, D-2907 (1973)

85) T.A. Norwid, J.F. Blount, J.A. Iacobelli, M.R. Uskokovic, Helv. Chım. Acta 57781 (1974)

86) J.C. Bontekoe, A. Wignall, M.P. Rappoldt, J.R. Roborgh, Int. Z. Vitaminforsch. 40589 (1970); C.A. 74 54078c

87) D.R. Crump, D.H. Williams, B. Pelc, J. Chem. Soc., Perkin I 19732731

88）金子主税, 山田幸子, 杉本昭子, 石川正幸, 佳々 木哲, 須田立雄, 日本薬学会第94年会（1974年， 4 月仙台), 要旨集, II- 174

89) M. Fieser, L.F. Fieser, "Reagents for Org. Syn.” Vol. 3 p. 24, Wiley, N.Y. (1972)

90）実験担当。山田幸子，杉本昭子，金子主税

91）坂本治雄，杉本昭子，金子主税，佐々木哲，須田 立雄, 未発表データー

92）金子主税，杉本昭子，山田幸子，江口征大, 石川 正幸, 須田立雄, 鈴木ミチ子，传々木哲，反応と 合成の 進歩シンポジウムーライフサイエンスを志
向した理論, 反応および合成，1974年11月，発表 予定 (予稿集, P-47)

93a) H.Y. Lam, B.L. Onisko, H.K. Schnoes, H.F. DeLca, Biochem. Biophys. Res. Comm. 59845 (1974)

b) A.W. Norman (Dept. of Biochem., Univ. of California), 私信

94) M.H. Imrie, P.F. Neville, A.W. Snellgrove, H.F. DeLuca, Arch. Biochem. Biophys. 120 525 (1967)

95) P.F. Neville, H.F. DeLuca, Biochemistry 5 2201 (1966)

96) H.F. DeLuca, M. Weller, J.W. Blunt, P.F. Neville, Arch. Biochem. Biophys. 124 122(1968)

97) T. Suda, R.B. Hallick, H.F. DeLuca, Analytical Brochem. 43139 (1971)

98) P.A. Bell, E. Kodicek, Biochem. J. 116755 (1970)

99) D.E.M. Lawson, R.W. Wilson, E. Kodicek, Biochem. J. 115269 (1969)

100）長谷川賢，臨床薬理 4310 (1973)；P.D. Klein, 薬物代謝 559 (1974)

101) N. Ikekawa, M. Morisaki, K. Tsuda, T. Yoshida, Steroids 1241 (1968); N. Ikekawa, K. Tsuda, M. Morisaki, Chem. Ind. 19661179

102) N. Ikekawa, M. Morisaki, H. Ohtaka, Y. Chiyoda, Chem. Commun. 1971 1498; H. Ohtaka, M. Morisaki, N. Ikekawa, J. Org. Chem. 381688 (1973)

103) A. Rotman, Y. Mazur, J. Chem. Soc. Chem. Commun. 197415

104) R.M. Dodson, A.H. Goldkamp, R.D. Muir, J. Amer. Chem. Soc. 824026 (1960); 793921 (1957)

105) A.S. Clegg, W.A. Denny, E.R.H. Jones, G.D. Meakins, J.J. Pinhey, J. Chem. Soc. Perkin trans 19732137

106) M.Nagasawa, M. Bae, G. Tamura, K. Arima, Agr. Bıol. Chem. 331644 (1969)

107) T.M. Chalmers, M.W. Davie, J.O. Hunter, K.F. Szaz, B. Pelc, E. Kodicek, The Lancet. 1973696

108) M. Peacock, J.C. Gallagler, B.E. C. Nordin, The Lancet. 1974385

109）若生宏, 谷口繁, 鈴木潤, 広岡豊, 広田正子, 佳 々木卓，金子主税，石川正幸，佐々木哲，須田立 雄, 阿部実, 第 8 回骨代謝研究会, 1974年6月(東 京), 要旨集 $\mathrm{p}-17$

110）広岡豊，佐々木卓，広田正子，金子主税，石川正 幸，佐々木哲，須田立雄，若生宏，第 8 回骨代謝 研究会, 1974年 6 月 (東京), 要旨集 $\mathrm{p}-18$

111) P.F. Brumbaugh, M.R. Haussler, J. Biol. Chem. 2491251 (1974) 